\title{
التنظيم القانوني للعمل الطبي عن بعد (دراسة في القانون الفرنسي)
}

\author{
بجاث مفرم الى مؤهمر \\ الجوانب القانونيتّوالاقتصاديتللذكاء كاء الاصطناعي \\ وتكنولوجيا المعلوماتي

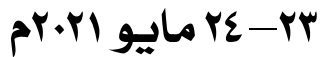 \\ كليتا الحقوق-جامعت المنصورة
}

shel

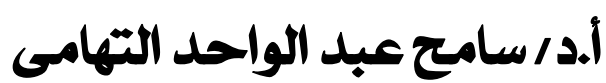

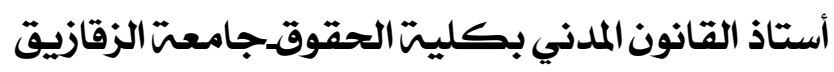

وكيل الكليتلشؤون خدمت المجتمع وتنميتة البيئت 
عدد خاص بالمؤتمر الدولى السنوى العشرون أ. د/ ساميح عبد الواحد التهامى

\section{المتدمة}

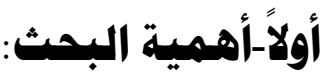

أثر التطور التكنولوجي في كثير من مناحي الحياة، ولعبت التكنولوجيا الحديثة

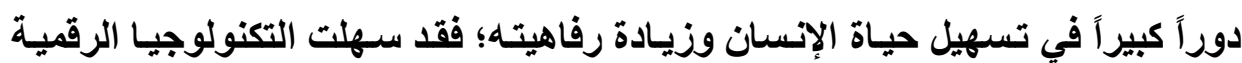
ووسائل الاتصال الحديثة للأفراد التواصل عن بعد، وسمحت لكثير من الجهات بتقديم خدماتها للأفراد عن بعد، سواء عن طريق تطبيقات الهاتف الأكي أو عن طريق مواقع شبكة الإنترنت.

ومن المجـالات التي أثرت فيها تكنولوجيا المعلومـات تأثيراً إيجابياً هو مجـال الرعاية الصحية؛ حيث أدت تكنولوجيا المعلومات إلى ظهور أجهزة طبية حديثة تلعب فيها البرمجيات دوراً هاماً في تثخيص الأمراض، وظهر ذلك جلياً في التطورات التي حدثت في أجهزة الأشعة وأجهزة التحاليل، كما أثرث التكنولوجيا الحديثة تأثيراً كبيراً فـى إدارة منظومـة الرعايـة الـصحية، حيـث أصسبحت إدارة المنششآت الـصحية إدارة إلكترونيـة سـواء مـا يتعلث بتنظيم سبر العـل داخل المنشأة أو تنظيم الملفـات الطبية للمرضي.

إلا أن أهم تأثير أحدثته تكنولوجيا المعلومـات في المجـال الطبي هو تأثير هذه التكنولوجيا في العلاقة بين الطبيب والمريض أو العلاقة بين الأطباء بعضهم البعض

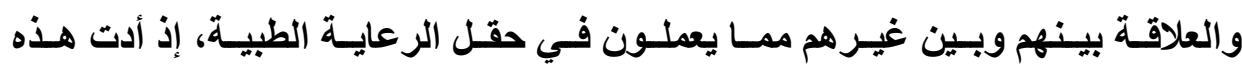
التكنولوجيا إلى إمكانيـة علاج المريض دون حاجـة لحضور المريض للطبيب، وإنمـا يتقابل الطبيب مـع المريض عن طريق وسيلة مـن وسـائل التواصل عن بعد، وكذلك تثاور الطبيب مع غيره من الأطباء أثناء قيامه بعلاج المريض. 
عدد خاص بالمؤتمر الدولى السنوى العشرون أ. د/ سامح عبد الواحد التهامى

فلقد أصبح العمل الطبي عن بعد من الأنشطة الطبية المعتادة في الكثير من

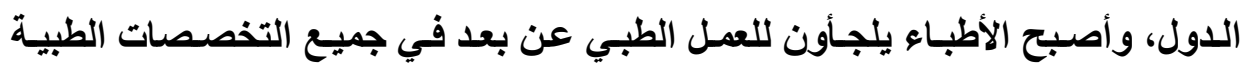

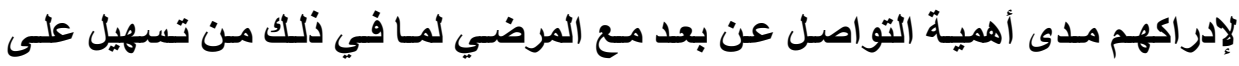

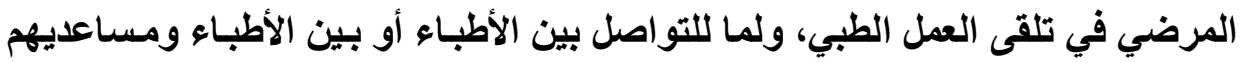

من أهمية في تحسين جودة العمل الطبي. (')

كمـا أن المـريض أصبح يفضل اللجـوء للوسـائل التكنولوجيـة التـي تسهل لـهـ

الحصول على العمل الطبي بدلاً من تحمل عناء الذهاب لمكان الرعاية الطبية والانتظـار

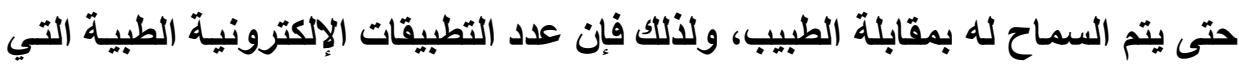

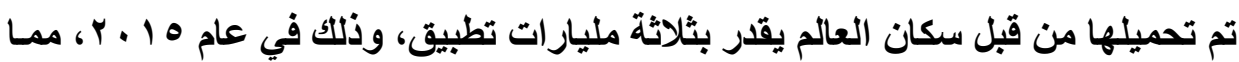

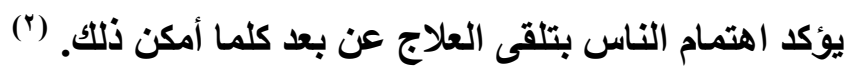

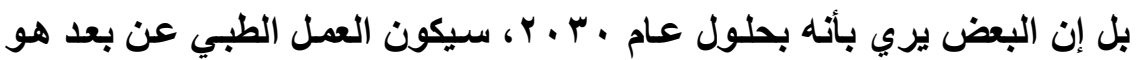

الأساس والعمل الطبي التقليدي سيكون هو الاستثناء، بمعنى أن نسبة العمل الطبي عن بأن

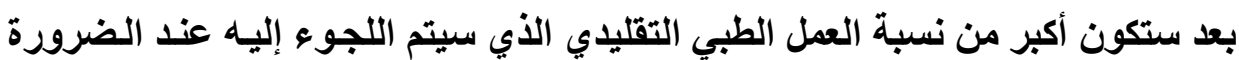

فقط.

(1) من أمثلة المواقع الإكترونية الثهيرة التي تقدم العمل الطبي عبر الإنترنت:

https://www.deuxiemeavis.fr

https://www.dred.com

https://www.zavamed.com

(2) Anaïs RICHARDIN, Face à la rigidité réglementaire française: la télémédecine peut-elle révolutionner la santé ?, Art disponible sur: https://www.maddyness.com/author/anais-richardin/, La date de mise en ligne est: 21 mars 2016.

(3) Denis PIVETEAU, La recherche d'un nouveau modèle économique, en dossier: Quelle santé à domicile pour demain ?: Enjeux et perspectives, Fédération des prestataires de santé à domicile, France, Janvier 2015, P 17. 
عدد خاص بالمؤتمر الدولى السنوى العشرون أ. د/ سامع عبد الواحد التهامى

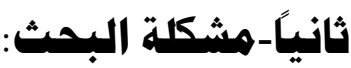

إن ممارسـة العمل الطبي عن بعد يثير بعض المشكلات الخاصـة بمدى كفـاءة

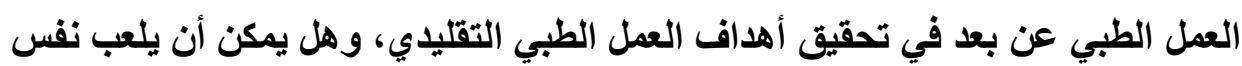
الدور الأي يلعبه العمل الطبي في صورته التقليدية؟

وما الضوابط القانونية لهذا العمل الطبي عن بعد حتى يحقق هذه الأهداف ولا

يكون مصدر خطر للمريض؟

وكيف يمكن المحافظة على خصوصية المريض في العمل الطبي الذي يجري

عبر وسـائل تكنولوجيـا المعلومـات، وكيف يمكن الحصول على رضساء مستنير من المريض عن كل إجراء طبي يتم عن بعد.

ثالثًا-هنهمج البحث:

حتى نجب عن هذه التساؤلات فسوف نتبع المنهج الوصسفي وذلك بلراسـة

التظيم القانوني للعمل الطبي عن بعد فى القانون الفرنسي لبحث أسس وتفصيلات هذا

التظظيم، لنرى مدى إمكانية قيام القواعد التشريعية في القانون الفرنسي بوضع حل بل

للمشكلات التي قد يسببها العمل الطبي عن بعد.

- Michael COHEN, Telemedicine: The Future of Health Care, Art on the internet at: www.legalzoom.com, the date of publishing is: February 2014. 
عدد خاص بالمؤتمر الدولى السنوى العشرون أ. د س سامح عبد الواحد التهامى

\section{رابعًا-خطة البحث:}

حتى نتــاول التنظيم القـانوني للعمل الطبي عن بعد، فسوف نتنـاول ماهيـة العمل

الطبي عن بعد ، ثم نتناول الضوابط القانونية للعمل الطبي عن بعد.

ويناءً على ذلك فسوف نقوم بتقسيم هذه الدراسة إلى:

الفصل الأول: ماهية العمل الطبي عن بعد.

الفصل الثاني: الضوابط القانونية للعمل الطبي عن بعد. 
عدد خاص بالمؤتمر الدولى السنوى العشرون أ. د/ ساميح عبد الواحد التهامى

\section{الفصل الأول}

\section{هاهية العهمل الطببي عن بهد}

تمهي⿻ وتقسيم:

وضع المشرع الفرنسي تنظيماً قانونياً متكاملاً للعمل الطبي عن بعد، حيث قام

المشرع الفرنسي بإضافة الفصل السادس للكتاب الثالث من القسم السادس من قانون

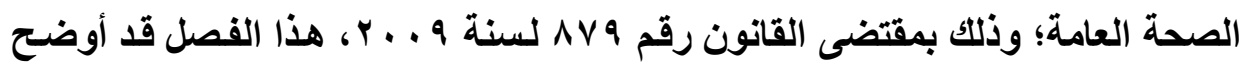
مفهوم العمل الطبي عن بعد، واعترف به كأحد وسائل ممارسـة العمل الطبي المسموح بها في مجال الرعاية الطبية. (1)

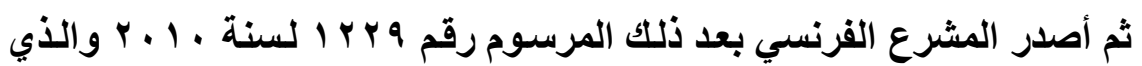
تضمن التظيم القانوني الكامل للعمل الطبي عن بعد، فقد أضساف هذا المرسوم مواداً جديدة للفصل الخاص بالعمل الطبي عن بعد في قانون الصحة العامة؛ حيث تتضمن هذه

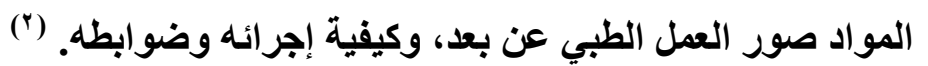
وحتى نتناول ماهية العمل الطبي عن بعد، فسوف نتناول المقصود بالعمل الطبي بصفة عامة، ثم نتنـاول المقصود بالعمل الطبي عن بعد، وأخيرا نتنـاول أهمية العمل

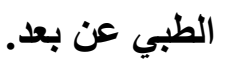

(1) Loi $n^{\circ}$ 2009-879 du 21 juillet 2009 portant réforme de l'hôpital et relative aux patients, à la santé et aux territoires, JORF, n'0167 du 22 juillet 2009, $p$ 12184, texte $n^{\circ} 1$.

(2) Décret $n^{\circ} 2010-1229$ du 19 octobre 2010 relatif à la télémédecine, JORF, $n^{\circ} 0245$ du 21 octobre 2010, texte $n^{\circ} 13$. 
عدد خاص بالمؤتمر الدولى السنوى العشرون أ. د سامح عبد الواحد التهامى

وذللك من خلال تقسيم هذا الفصل إلى:

المبحث الأول: المقصود بالعمل الطبي عن بعد.

المبحث الثاني: صور العمل الطبي عن بعد.

المبحث الثالث: أهمية العمل الطبي عن بعد.

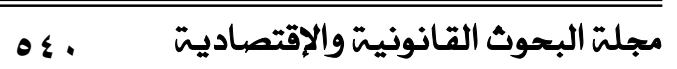


عدد خاص بالمؤتمر الدولى السنوى العشرون أ. د/ سامح عبد الواحد التهامى

\section{المبحث الأول \\ الاقصود بالعمل الطبي عن بعد}

حتى نحدد المقصود بالعمل الطبي عن بعد، فسنتناول تعريف العمل الطبي عن بعد الوارد في قانون الصحة العامة الفرنسي، وذلك في المطلب الأول، ثم نقوم بـالتمييز بين مصطلح العمل الطبي عن بعد والمصطلحات الأخرى التي قد تتشابه معله، وذلك في المطلب الثاني.

\section{الاطباب الأول}

\section{تعريف العمل الطبي عن بعد}

نصت المادة (L6316-1) من قانون الصحة العامة الفرنسي على تعريف العمل

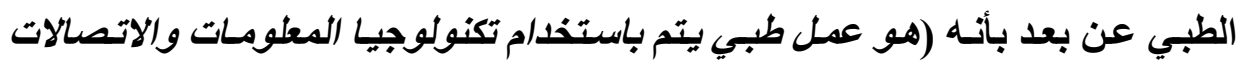

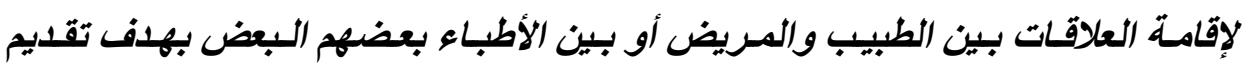

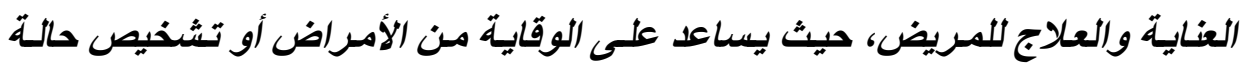

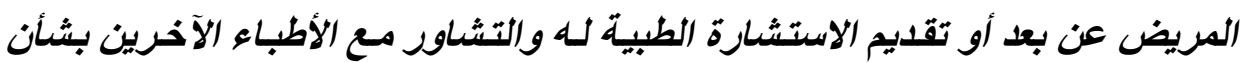
حالته واتخاذ القرار العلاجى ووصف الدواء ومتابعة المريض أثناء العلاج). والملاحظ على هذا التعريف أنـه وصف العمل الطبي عن بعد بأنه عمل طبي،

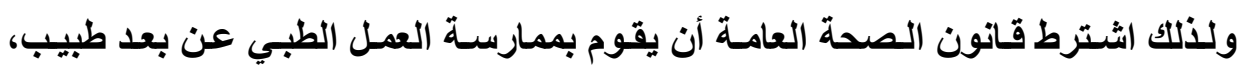
فالعمل الطبي عن بعد هو عمل طبي عادي ولكن يقدم عن طريق وسيله من وسـائل

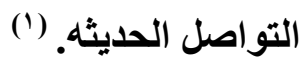

(1) Jean-Louis ARNÉ, Éthique: jurisprudence et télémédecine, Bull. Acad.

Natle Méd, 2014, 198, $\mathrm{n}^{\circ}$ 1, P 119-130. 
عدد خاص بالمؤتمر الدولى السنوى العشرون أ. د/ سامح عبد الواحد التهامى

فالمشرع نظر للعمل الطبي عن بعد باعتباره عملاً طبيّاً تقليَيَّاً يُمارس باستخدام

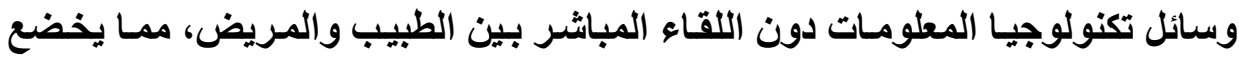

هذا العمل الطبي عن بعد لذات القواعد القانونية للعمل الطبي العادى ماعدا ماتقتضيه لكونيه

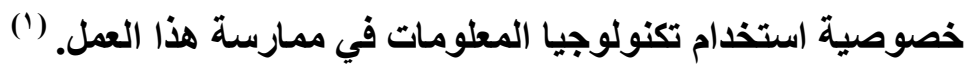

فالعمل الطبي عن بعد هو استخدام تكنولوجيا المعلومـات والاتصالات في تقديم

العمل الطبـي للمـريض؛ حيـث إن المـريض والطبيـب لـن يتقـابلا وجهاً لوجـه، ولكـن

سيتقابلان عبر الوسيلة التكنولوجية.

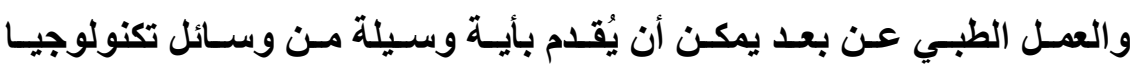

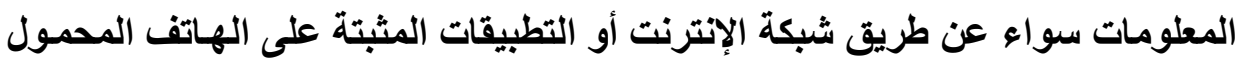

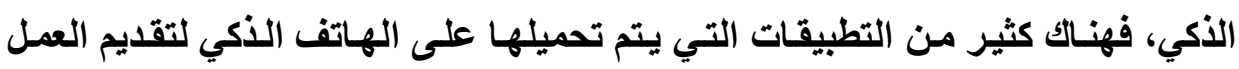

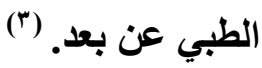

\section{الامثب الثاني}

\section{التمييز بين هصطاح العمل الطببي عن بعد ومايشتبه به}

هنـاك بعض المصطلحات التي يمكن أن تتشابه مـع مصطلح العـل الطبي عن

بعد، وبالتالي يكون من الواجب التمييز بين هذه المصطلحات ومصطلح العمل الطبي

(1) David GRUSON, Il faut déverrouiller le modèle économique de la télémédecine, Art disponible sur: www.editions-legislatives.fr, La date de mise en ligne est: 22/07/16.

(2) Jean HERVEG, Confidentialité et sécurité pour les applications de télémédecine en droit européen, revue hospitalière de France, vol. 12, $\mathrm{n}^{\circ} 1$ (Printemps / Spring 2007).

- Thomas SYBURRA et Michele GENONI, Applications de la télémédecine en Suisse, Rev Med Suisse, 2008, 4, P 2652-2656.

(3)Thierry SIRDEY, Prudence avec les applications mobiles et les logiciels de santé, Art disponible sur: www.larecherche.fr/parution/mensuel-510, la date de mise en ligne est: avril 2016. 
عدد خاص بالمؤتمر الدولى السنوى العشرون أ. د/ سامح عبد الواحد التهامى

عن بعد، وهذه المصطلحات هي مصطلح النصيحة الطبية عن بعد ومصطلح الخدمة الصحية الإكترونية.

فالنصيحة الطبية عن بعد هي مجرد تقديم النصائح الطبية على شبكة الإنترنت،

أو عن طريق تطبيقات الهاتف المحمول، ولا تعد النصيحة الطبية عن بعد عمل طبي؛

و إنما هي مجرد تقديم معلومات طبية عامة لتحسين الصحة، ولا تلدخل في إطسر العمل

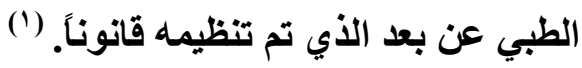

فالنصيحة الطبية عن بعد لا تتضمن تشخيص مرض معين أو وصف علاج أو

دواء، وإنما هي مجرد نصيحة طبية عامة غير متعلقة بحالة شخص معين، ولذلك فيان المادة (R4127-53) من قانون الصحة العامة الفرنسي نصت على عدم جواز تقاضى

$$
\text { الطبيب أي أجر على إعطاء نصيحة طبية عن بعد. }
$$

ولذلك فالنصيحة الطبية عن بعد لا تعد عملاً طبياً عن بعد، ويجوز القيـام بها

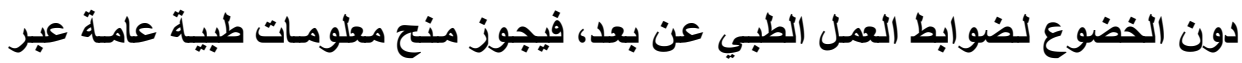

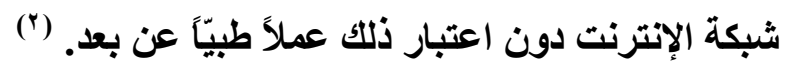

ففي النصيحة الطبية عن بعد لا يطلع الطبيب على الحالة المرضية للمريض

ولا بياناتـهـ الـصحيه، ولا يشخص مرضـاً أو يصف علاجـاً، هو فقط يمـنح معلومــاتٍ

(1) Pierre SIMON, la télémédecine clinique : un modèle français, Lex Electronica, $n^{\circ}$ 560, septembre - octobre 2014, P 42-45.

(2) David GRANEL, E-santé: la téléconsultation peine à se développer en France, Art disponible sur:www.jurilexblog.com, la date de mise en ligne est: 25 avril 2016.

- Marcel POCHARD et Autres, Vade-mécum télémédecine, conseil national de l'Ordre des médecins, France, SEPT 2014, P 18. 
عدد خاص بالمؤتمر الدولى السنوى العشرون أ. د/ سامح عبد الواحد التهامى

طبيـة عامسة لمـن يطلب هذه النـصيحه دون أن تـرتبط هـذه النصيحة بحالـة مـريض

(') معين. (1)

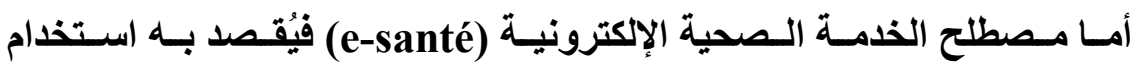

تكنولوجيـا المعلومسـات فـي كـل نـواحي إدارة الخدمـة الـصحيه، سـواء إدارة ملفــات

المرضى، أو إدارة المنشآت الطبية، أو علاقة العاملين في الخدمـة الصحية مـع بعضهم

البعض أو العلاقة مـع المريض، وبالتـالي فالعمـل الطبي عن بعد هو مجرد جزء من

(الخدمة الصحية الإلكترونية.

فمصطلح الخدمة الصحية الإكترونيـة هو مصطلح أعم وأوسـع من مصطلح

العمل الطبي عن بعد، وهو أقدم في الظهور من مصطلح العمل الطبي عن بعد، وهو

يـشمل العـل الطبـي عـن بعـد باعتبـاره أحــث صـورة مسن صـور الخدمـة الـصحية الإكترونية.

(1) Cécile MONTEIL, Télémédecine : quand l'Ordre des Médecins se met en colère, Art disponible sur: http:www.lequotidiendumedecin.fr, la date de mise en ligne est: 24 février 2016.

(2) Anne BEAUFORT et Alice PHILIPPOT, Innovation médicale : le corps ou l'objet ?, Art disponible sur: www.tendancedroit.fr/lin novationdans-le-domaine-de-lasante, la date de lire: 11 décembre 2016.

- Pierre SIMON et Jacques LUCAS, La telemedicine: ce n'est pas du ecommerce, Rev de la Recherche Européenne en Télémédecine, V.3, Issue 1, March 2014, PP 27-34.

- Francis SERBAROLI, Telemedicine: Legal And Practical Considerations, NYLJ, V. 251, ํ 100, 27 MAY 2014.

- Mark KADZYELSKI \& Jee KIM, Telemedicine: Many Opportunities, Many Legal Issues, Many Risks, AHLA Connections Journal (July 2014). 
عدد خاص بالمؤتمر الدولى السنوى العشرون أ. د/ ساميح عبد الواحد التهامى

\section{البمشث الثثاني \\ أهمية العهمل الطبي عن بهد}

هل العمل الطبي عن بعد يمكن أن يكون له فائدة أو أهمية كبيرة تجعل المُشرّع يتدخل لوضع تنظيم قانوني له؟

مما لا شك فيه أن العمل الطبي عن بعد له عدة فوائد، مما جعل البعض يري فيه

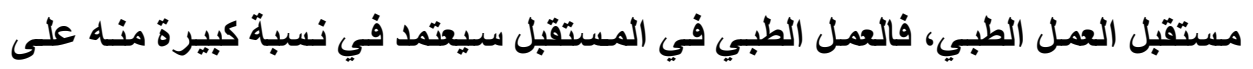

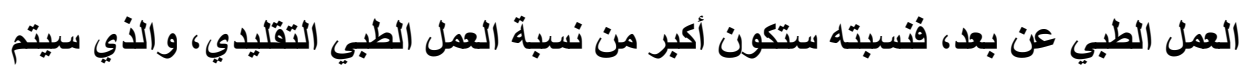
اللجوء إليه عند الضرورة فقط. (1)

تتمثل الفائدة الأولى لممارسة العمل الطبي عن بعد فى أنسه يوفر الوقت والجها

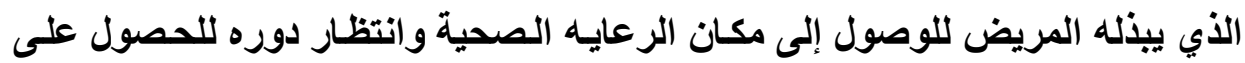

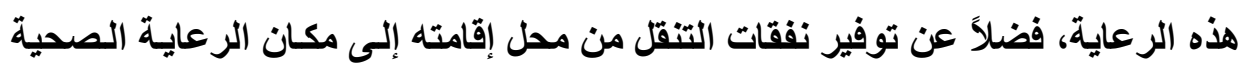
سواء كانت مستشفى أو مركزاً طبيّاً أو عيادة خاصة.

ويلعب العمل الطبي عن بعد دوراً محورياً في متابعة المريض بعد القيام بعدل

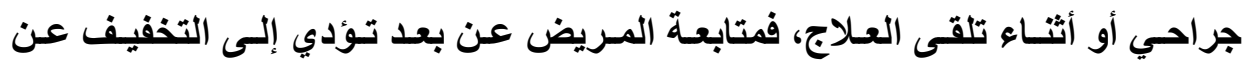

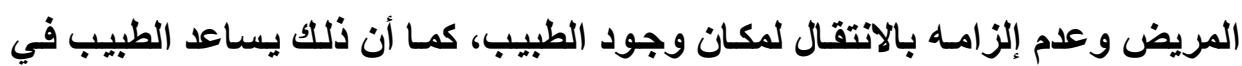

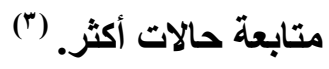

(1) Michael COHEN, Telemedicine: The Future of Health Care, Op.cit.

(2) Jean-Louis ARNÉ, Éthique: jurisprudence et télémédecine, Op.cit.

(3)Cécile FRATELLINI, Télémédecine : se soigner à distance, Art disponible sur: http://www.essentiel-sante-magazine.fr/sante/acces-auxsoins/telemedecine-soin-distance, la date de mise en ligne est: 24/09/2013. 
عدد خاص بالمؤتمر الدولى السنوى العشرون أ. د/ سامح عبد الواحد التهامى

ويلعب العمـل الطبي عـن بعد دوراً هامساً في حسالات الطوارئ، مثُل الحسالات

المتعلقة بالسكتة الدماغية أو الأمراض المزمنـة أو السكته القلبيه، حيث يمثل العمل

الطبي عن بعد حلاً سريعاً لهذهذ الحسالات الطارئهة؛ لأن انتقال المريض للطبيب يكون

صعباً وقد يتسبب في موته، كمـا يمثل العـل الطبي عن بعد الحل الأمثل لكبار السن

الأين يصعب أو يستحيل انتقالهم إلى أماكن الرعاية الطبية. (1)

ويمثل العمل الطبي عن بعد وسيلة جيدة لتقديم بعض الخدمات الطبية للمناطق

النائية بلون حاجة لإقامة مراكز طبية في هذه المناطق، فالعمل الطبي عن بعد يمكن أن

يكون حلاً لكثير من مشكلات الرعايـة الصحيه وذلك بتقديم بعض الخدمات الطبية

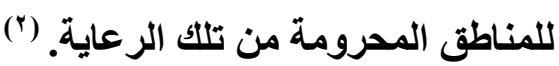

فأحد الأهداف الرئيسة للعمل الطبي عن بعد هو المساواة بين المواطنين في

الحصول على خدمة طبية ذات جودة عالية في جميع أرجاء البلاد؛ وذلك لتحقيق الحق

الأساسي لكل مواطن في الرعاية الصحية، فالعمل الطبي عن بعد يسمح للمريض في

المنـاطق النائيـة بالحصول على ذات الخدمـة الطبيـة التي يحصل عليهـا المريض في

العاصمة وبذات المستوي.

(1)Nicolas GIRAUDEAU, L'acte médical à l'épreuve de la télémédecine bucco-dentaire, thèse pour obtenir le grade de docteur, l'école doctorale Droit et Science politique Et de l'unité de recherche, Université Montpellier 1, 2014, $P$ 8.

(2) Nicolas SAMARCQ et Sébastien BRIOIS, Télémédecine : quel cadre juridique, Art disponible sur: http://www.echosjudiciaires.com/category/culture/gironde-actualites, La date de mise en ligne est: 28 décembre 2012.

(3) Nicolas GIRAUDEAU, L'acte médical à l'épreuve de la télémédecine bucco-dentaire, Op.cit, $P \backslash 19$. 
عدد خاص بالمؤتمر الدولى السنوى العشـرون أ. د سامع عبد الواحد التهامى

ولذلك فقد بأت كثير من مشروعات العمل الطبي عن بعد في الدول الإفريقية وذلك باعتباره وسيلة لتقديم الرعاية الصحية للمواطنين بتكلفة أقل وتوصيل الرعايـة الصحية للمدن البعيده عن العاصمة، وتقديم الرعاية الطبية عن بعد من أطباء مقيمين

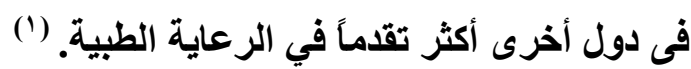

ولذلك يري البعض أن العمل الطبي عن بعد هو أحد الوسائل التي من الممكن أن تلجأ إليها الحكومات لتقليل الفوارق بين المنـاطق المختلفة في الحصول على الرعايـة الطبية؛ بحيث تسمح هذه الوسيلة بمنح الرعاية الطبية للمناطق البعيدة والنائية بنفس لئس لئس المستوى الذي يحصل عليه المواطن في العاصمة. (ن)

ولذلك فقد نصت المادة (L.6316-1) من قانون الصحة العامـة الفرنسي على أن إنشاء أنظمة العمل الطبي عن بعد يجب أن تأخذ بعين الاعتبار القصور في تقديم الخدمة الطبية للمناطق الجغرافية النائية.

وبالتالي فالعمل الطبي عن بعد يهدف إلى أن تمتد أوجه الرعاية الطبية للمناطق النائية التي قد تكون محرومة من بعض أوجه الرعاية الطبية أو تحصل عليها، ولكن بمستوى أقل من المستوى الأي يحصل عليه الأفراد القاطنين بالمدن الكبرى، أو تكون محرومة من بعض التخصصات الطبية الدقيقة، فالعمل الطبي عن بعد هو أمل لتحقيق المساواة بين المواطنين في الحصول على الخدمة الطبية؛ حيث يتم تزويد الوحدات

(1) Olivier MONNIER, La télémédecine, une chance pour l'Afrique, Art disponible sur: www.la-croix.com, La date de mise en ligne est: 10 June 2013.

(2) Nathalie DEVILLIER, La télémédecine : une innovation de rupture, Art disponible sur: www.lesechos.fr, la date de mise en ligne est: 02/06/2015. 
عدد خاص بالمؤتمر الدولى السنوى العشرون أ. د/ سامح عبد الواحد التهامى

الطبية في المناطق النائية بأدوات الاتصال وتكنولوجيا المعلومات، حتى يمارس الطبيب الموجود بالعاصمة العمل الطبي عن بعد ويمنحه للمريض المعـالج بتلك الوحدة الطبية

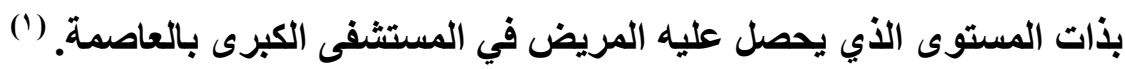
ويعتبر العلاج النفسي عن بعد حلاً مناسباً للمرضس الذين يخجلون من الذهاب

للطبيب النفسي، حيث يقابلون الطبيب النفسي وهم موجودون في منـازلهم بـدون حاجة للأهاب إلى عيادته وذلك عبر وسيلة تكنولوجية للتواصل عن بعد. (r) ويلعب العمل الطبي عن بعد دورا هامـا في تدريب الأطباء؛ حيث يتواصل الطبيب

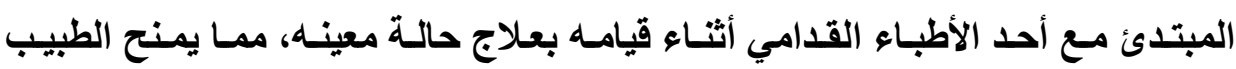
المبتدئ التدريب اللازم، ويؤدى إلى نقل الخبرة بين أجيال الأطباء، ويؤدى إلى إثراف

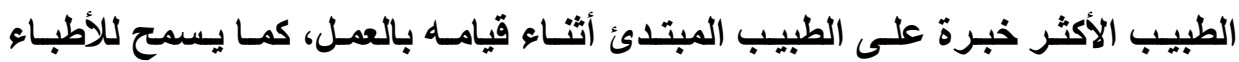
بممارسة العمل الطبي بشكل جماعى عن بعد دون حاجة للتلاقي في مكان واحد. (َ) كما أن العمل الطبي عن بعد يلعب دوراً هاماً في تقليل نفقات الرعايـة الصحية،

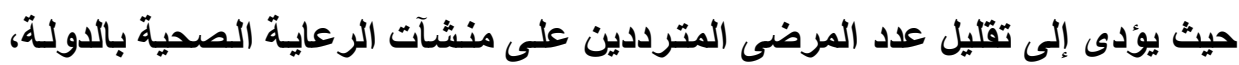
مما يقلل من عدد هذه المنشآت وبالتالي تقليل ميزانية الرعايـة الصحية في الموازنـة

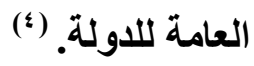

(1) Nicolas GIRAUDEAU, Op.cit, P 212-211.

(2) Jessica Nadeau, La psychothérapie à distance pour traiter l'anxiété généralisée, Art disponible sur: http://www.ledevoir.com, La date de mise en ligne est: 8 juillet 2015.

(3) Marcel POCHARD et Autres, Vade-mécum télémédecine, Op.cit, P 8.

(4) Vincent RICOULEAU, Les enjeux juridiques de la télémédecine, Art disponible sur: www.Village-justice.com, la date de mise en ligne est: 21 octobre 2014.

$=$ 
عدد خاص بالموتمر الدولى السنوى العشرون ا.. د/ سامح عبد الواحد التهامى

كما أن العمل الطبي عن بعد يعطى المريض فرصة كبيرة للاختيار بين الأطباء

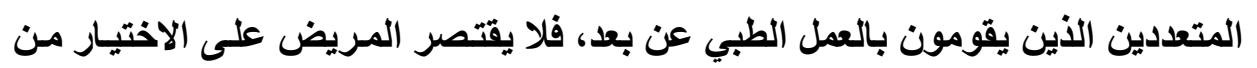

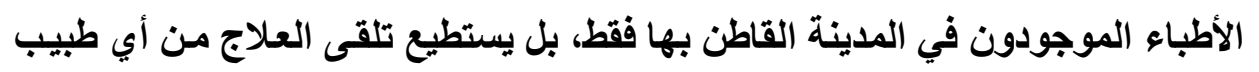

أيا كان مكانه في أي مكان بالعالم. (')

- Bill MARINO \& others, A Case for Federal Regulation of Telemedicine in the Wake of the Affordable Care Act, Colum. Sci. \& Tech. L. Rev, VOL. XVI, spring 2015, pp 274-357.

(1) Nicolas GIRAUDEAU, Op.cit, P 123. 
عدد خاص بالمؤتمر الدولى السنوى العشرون أ. د/ سامح عبد الواحد التهامى

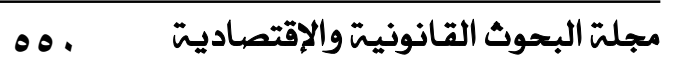


عدد خاص بالمؤتمر الدولى السنوى العشرون أ. د/ سامح عبد الواحد التهامى

المبحث الثالث

\section{صور العمل الطببي عن بعد}

نصت المادة (R316-1) من قانون الصحة العامة الفرنسي على صور العمل

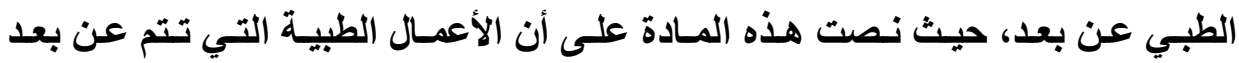
باستخدام أداة من أدوات تكنولوجيـا المعلومـات والاتصال تتمثل في الاستشارة الطبية

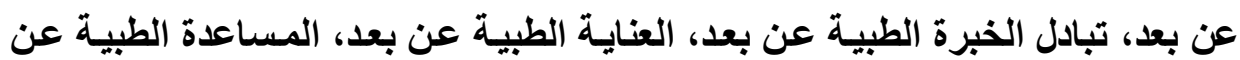

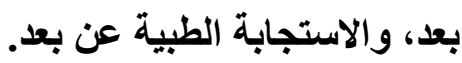
سوف نتناول المقصود بكل صورة من تللك الصور كل في مطلب مستقل.

\section{الإطباب الأول}

\section{الاستشارة الطبية عن بعد}

عرفت المادة (R. 6316-1-1) من قانون الصحة العامة الاستثارة الطبية عن

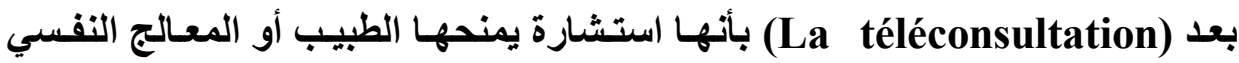

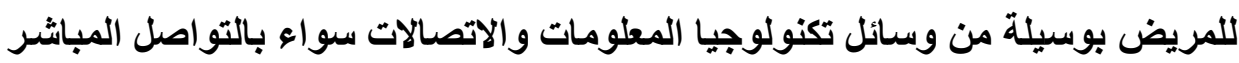

بين الطبيب والمريض فقط أو بين الطبيب والمريض في وجود أحد مساعدي الطبيب. والاستشارة الطبية عن بعد هي عمل طبي ولا تعد مجرد نصيحة يعطيها الطبيب

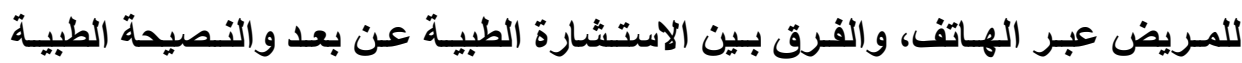

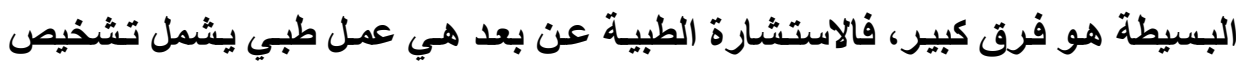

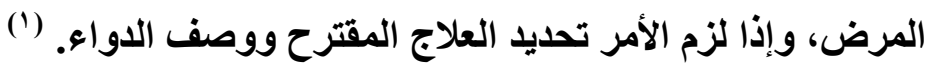

(1) Camille BOURDAIRE-MIGNOT, « Téléconsultation: quelles exigences? Quelles pratiques? », RDSS, Nov. déc. 2011, n 6, p. 1003. 
عدد خاص بالمؤتمر الدولى السنوى العشرون أ. د/ سامح عبد الواحد التهامى

وتبدأ الاستثارة الطبية عن بعد بالتشاور بين المريض والطبيب للاستفهام عن

الأعراض التي يعـاني منهـا المريض، ثم يسأل الطبيب المريض بعض الأسئلة، وقد يطلب منه قياس حرارته أو قياس ضغط اللدم أو كشف المنطقة المصابة أمسام الكاميرا للاطلاع عليهـا، ويطلـع الطبيب على كل الملف الطبـي الإكترونسي للمـريض بمـا قـد يتضمنه من نتائج التحاليل والأثعه ثم يقوم الطبيب بنـاءً على ذلك بتشخيص المرض الاض (1) ووصف العلاج.

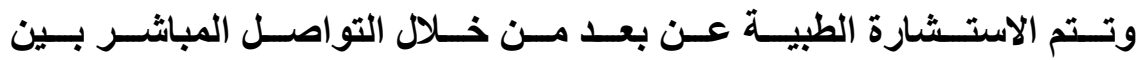

الطبيب والمريض عبر وسيلة من وسـائل تكنولوجيا المعلومـات، ومـن الممكن أن يتم

التواصل بين المريض والطبيب فقط وذلك إذا لم يكن هناك حاجة لفحص المريض، ومن الممكن أن يكون هنـاك مساعد طبيب(كـالممرض) مـع المريض يقوم بفحص المريض ونقل نتائج الفحص للطبيب مباشرة عن بعد، بحيث يشخص الطبيب المرض ويصف

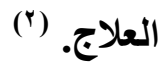

فمثثلاً المعـالج النفسي لا يكون في حاجـة لفحص المريض ولكنـهـ يحتـاج فقط للتواصل والتحدث معه لتشخيص حالته النفسية وتثخيص المرض النفسي الذي يعاني منه المريض، مما يؤدى إلى عدم حاجته لمساعد لفحص المريض والاكتفـاء بالتواصل

(1) Jesus CARDENAS, Des avancées dans la pratique de la médecine à distance, Art disponible sur: http://www.doctissimo.fr/sante/news/telemedecine-teleconsultationteleconseil, La date de mise en ligne est: 26 mai 2016.

(2) Marcel POCHARD et Autres, Vade-mécum télémédecine, Op.cit, P 9. 
عدد خاص بالمؤتمر الدولى السنوى العشرون أ. د/ سامح عبد الواحد التهامى

كمسا أن الطبيب في كثير مـن الحسالات لايكون في حاجـة إلى مسـاعد لفحص المريض، ويعتمد على البيانات التي يدلى بها المريض عما يشعر به من أعراض، وقد يطلب الطبيب من المريض أن يقوم بقياس حرارتـه أو قياس ضغط الدم، وقد يفحص الطبيب المريض عن بعد بالنظر للمكان الأي به المشكلة كالتهاب مثلاً، وذلك باستخدام كاميرا رقمية موجودة في الجهاز المستخدم من قبل المريض سواء كـان هاتفاً ذكيّاً أو كومبيوتر.

وطبيب الأسنان من الممكن أن يمـارس الاستشـارة الطبية عن بعد، وذلك في حالـة عدم الحاجـة إلى تـلـل جراحي، حيث يفحص طبيب الأسـنان فم المريض مـن خلال كـاميرا صغيرة يـتم إدخالها داخل تجويف الفم وتوجيهـها إلى المكان المصاب، بحيث يستطيع الطبيب تشخيص المرض ووصف العلاج عن بعد دون حاجة للفحص (') ( المباشر.

والجدير بالذكر هنا أن المشرع الفرنسي قد قام بتعديل المسادة (R. 5125-54)

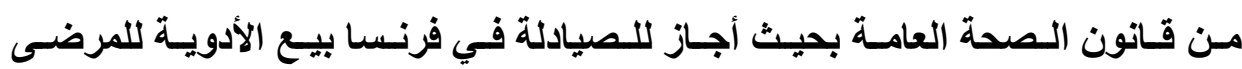
التي يطلبونها بنـاء على وصفة طبية صـادرة من طبيب موجود بإحدي دول الاتحساد

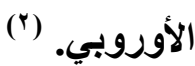

وهدف المشرع من هذا التعديل هو السماح للمريض الفرنسي بالحصول على استثارة طبية عن بعد من أي طبيب داخل الاتحاد الأوروبي، حيث يتمكن المريض من من من

(1) Nicolas GIRAUDEAU, Op.cit, P 98.

(2) Décret $n^{\circ}$ 2013-1216 du 23 décembre 2013 relatif à la reconnaissance des prescriptions médicales établies dans un autre Etat membre de I'Union européenne, JORF, n⿳0300 du 27 décembre 2013, P 21474, texte $n^{\circ} 21$. 
عدد خاص بالمؤتمر الدولى السنوى العشرون أ. د/ سامح عبد الواحد التهامى

شراء الدواء من أي صيدلية داخل إقليم دولـة فرنسا بمقتضى الوصفة الطبية التي يرسلها له الطبيب.

كمـا أن من شـأن ذلك أن يؤدى إلى سـماح الدول الأوروبية الأخرى لمرضـاها بالحصول على الاستشارات الطبية عن بعد مـن الأطبـاء الفرنسبين وإمكانيـة شـراء الاواء من صيدلية داخل هذه الدول، مما يكون له أثر إيبابي على تطور العمل الطبي عن بعد في كل الدول الأوروبية.

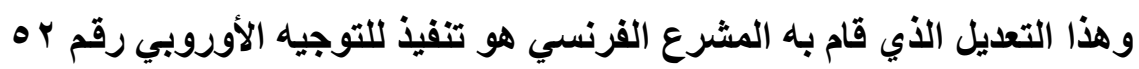
لسنة r l ـ r والخاص باجراءات تسهيل الاعتراف بالوصفات الطبية التي تصدر داخل دول الاتحاد الأوروبي في كل دول الإتحاد. (") الاملب الثاني

\section{تبادل الخبرة الطبية عن بعد}

عرفت المادة (R. 6316-1-2) من قانون الصحة العامـة تبادل الخبرة الطبية عن بعد (La téléexpertise) بأنها قيام الطبيب بطلب الرأي الطبي من واحد أو أكثر من الأطباء المتخصصين في تخصص دقيق أو من طبيب أكثر خبرة، وذلك بصدد حالة

(1) Christophe COURAGE, Prescriptions médicales européennes : un coup de pouce pour la télémédecine, Art disponible sur: www.juritravail.com, La date de mise en ligne est: 21-01-2014.

(2) Ibid.

(3) Directive d'exécution 2012/52/UE de la Commission du 20 décembre 2012, établissant des mesures visant à faciliter la reconnaissance des prescriptions médicales établies dans un autre État membre, JOUE, L 356, 55 e année, 22 décembre 2012, p 68. 
عدد خاص بالمؤتمر الدولى السنوى العشرون أ. د/ سامح عبد الواحد التهامى

المريض الذي يقوم بتشخيص حالته، بعد أن يرسل لهم كل البيانـات الصحية الخاصة بالمريض.

وبالتالي نلاحظ أن هذه الصورة من صور العمل الطبي عن بعد هي عبارة عن

علاقة عن بعد بين الأطباء لتبادل الرأي والخبرة الطبية لمساعدة أحدهم أثناء قيامسه

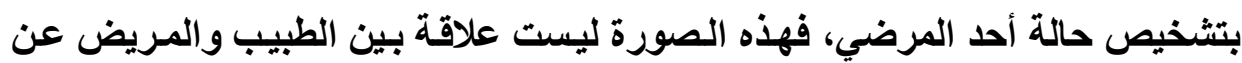
بعد، ولكنها علاقة بين الأطباء لخدمة هذا المريض. (') ويتم تبادل الخبرة الطبية بأن يتواصل الطبيب المعالج للمريض مع طبيب آخر

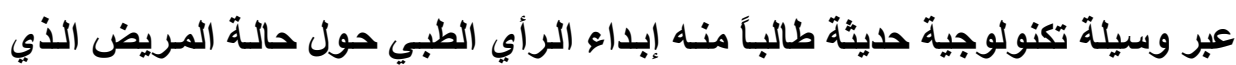
يقوم بعلاجه، ويقوم الطبيب المعالج بإرسال كل بيانات المريض الصحية للطبيب الآخر

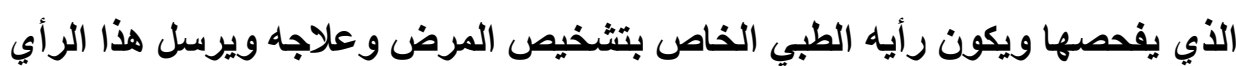

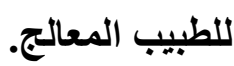

ونلاحظ أن قانون الصحة العامة صريح في اعتبار هذا التواصل بين الأطباء عن

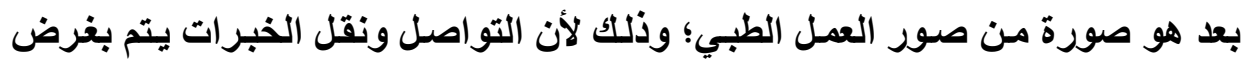

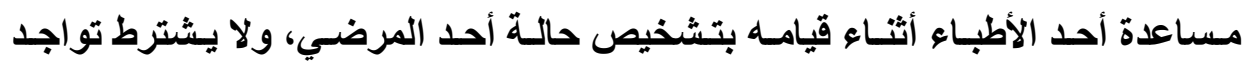
المريض أثناء قيام الأطباء بتبادل الخبرة الطبية، فتبادل الخبرة الطبية قد يتم في غيابه،

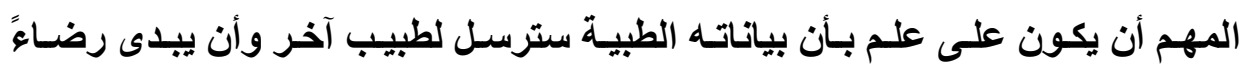

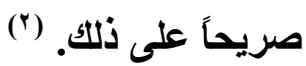

وفى الواقع فإن التواصل بين الأطباء موجود من قبل، فمن الشائع أن يتواصل

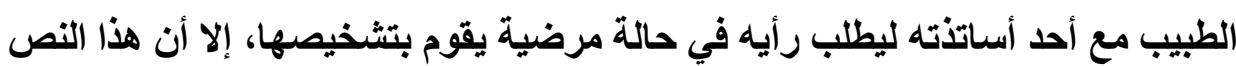

(1) Jesus CARDENAS, Des avancées dans la pratique de la médecine à distance, Op.cit.

(2) Marcel POCHARD et Autres, Vade-mécum télémédecine, Op.cit, P 910. 
عدد خاص بالمؤتمر الدولى السنوى العشرون أ. د/ سامح عبد الواحد التهامى

قد منح الثرعية لتبادل هذه الخبرات عبر الوسـائل التكنولوجية الحديثة، وكذلك تبادل البيانـات الصحية الخاصـة بـالمريض الذي يتم بحث حالته عبر تلكت الوسبائل، وتبـادل

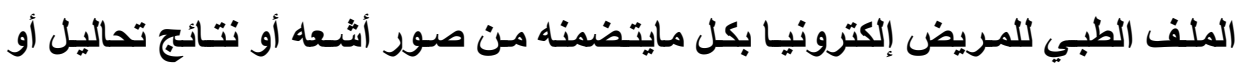
التاريخ المرضي للمريض. (1) وتبادل الخبرة الطبية هو أحد التزامات الطبيب وفقا للميثاث العالمى لآداب مهنة

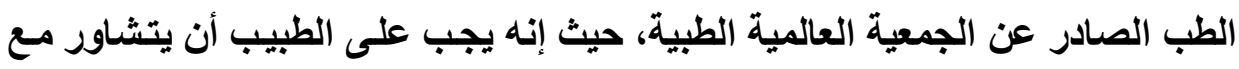

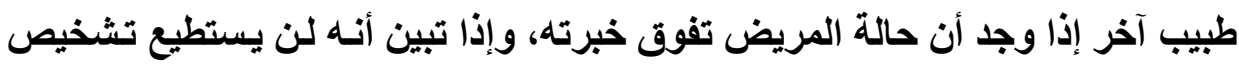

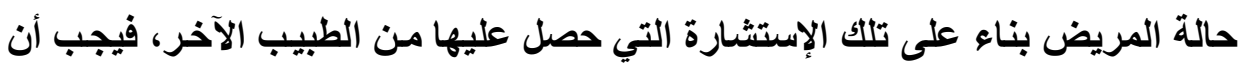

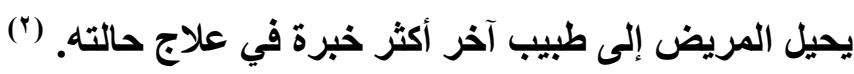
ويمكن القول إن تكنولوجيا المعلومـات تسهل على الطبيب تنفيذ هذا الالتزام،

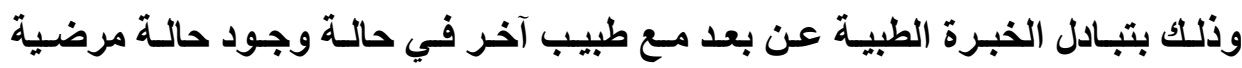
معروضة عليه وتفوق خبرته الطبية.

كما أن تبادل الخبرة الطبية عن بعد يكون إلزامياً عندما تتعلق حالة المريض

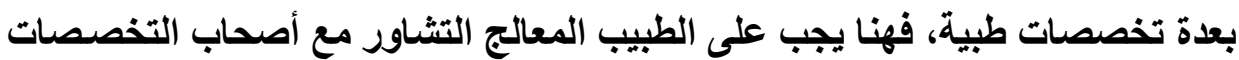
الأخرى قبل تثخيص المرض ووصف العلاج حتى لا يعالج مرض ويتسبب في تفاقم مرض آخر، ويلتزم الطبيب المعالج بإعطاء معلومات دقيقة وكاملة للطبيب الآخر الذي لأي

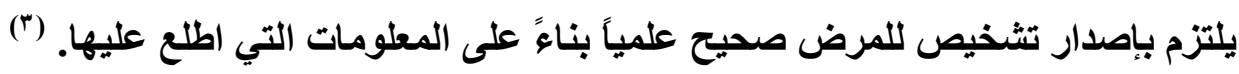

(1) Nicolas GIRAUDEAU,Op.cit, P 100.

(2) International Code of Medical Ethics, Adopted by the 3rd General Assembly of the World Medical Association, London, England, October 1949, and amended by the 57th WMA General Assembly, Pilanesberg, South Africa, October 2006, available at: http://www.wma.net/en/30publications/10policies/c8/index.html.

(3) Jean-Louis ARNÉ, Éthique: jurisprudence et télémédecine, Op.cit. 
عدد خاص بالمؤتمر الدولى السنوى العشـرون أ. د سامع عبد الواحد التهامى

وتبـادل الخبرة الطبيـة عن بعد متصور حدوثها في كل التخصصـات الطبيـة،

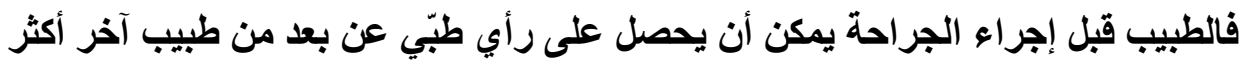

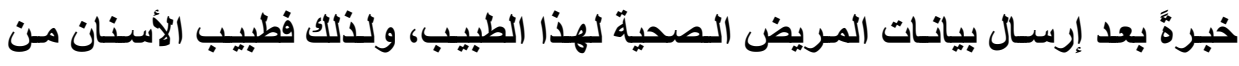
الممكن قبل إجراء جراحة للمريض أن يحصل على رأي طبيب آخر أكثر خبره بحالة المريض، وكذلك الأمر بالنسبة للمعالج النفسي أو أخصائي العلاج الطبيعي، فأي منهم إنه يستطيع أن يتشاور مع زميل له أكثر خبرة عبر وسيلة من وسائل التواصل عن بعد فيما يتعلق بحالة مريض منظورة أمامه.

\section{الامطلب الثالث}

\section{العناية الطبية عن بهد}

عرفت المادة (R. 6316-1-3) من قانون الصحة العامة العناية الطبية عن بعد بأنها تلقي الطبيب عن بعد بيانـات صحية (La télésurveillance médicale)

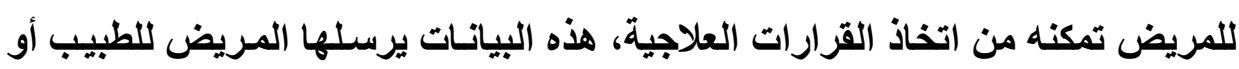
يرسلها مساعد طبيب للطبيب.

والعناية الطبية عن بعد هي أحد الأعمال الطبية التي يقوم بمقتضاها الطبيب

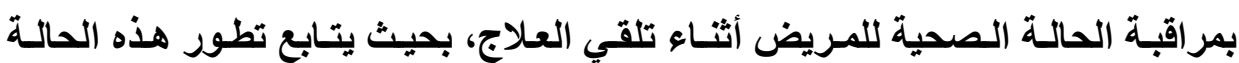

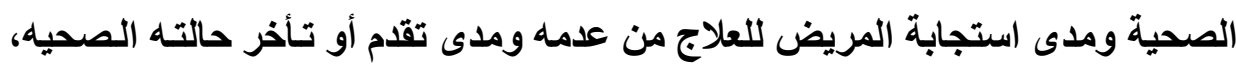

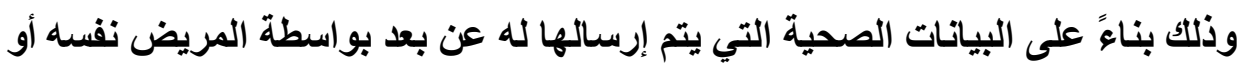
أحد مساعدي الطبيب. (') وتفترض هذه الصورة أن الطبيب قد فحص حالة المريض قبل ذلك سواء عن

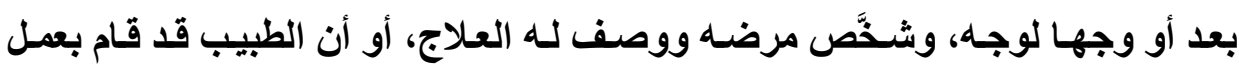

(1) Jesus CARDENAS, Des avancées dans la pratique de la médecine à distance, Op.cit. 
عدد خاص بالمؤتمر الدولى السنوى العشرون أ. د/ سامح عبد الواحد التهامى

جراحي للمريض، ودور الطبيب في هذه المرحلة أنه يقوم بمتابعة المريض أثناء تلقي العلاج أو بعد العمل الجراحي.

ونلاحظ أنه في هذه الصورة من صور العمل الطبي عن بعد، فِإن العلاقة تكون

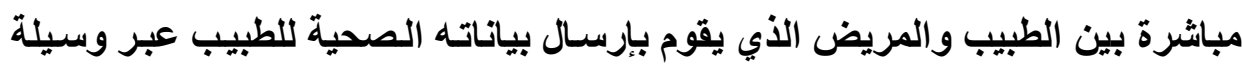

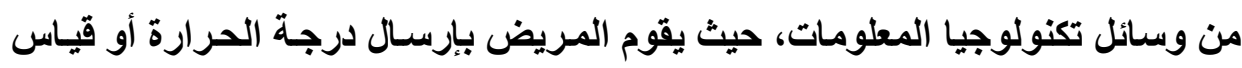

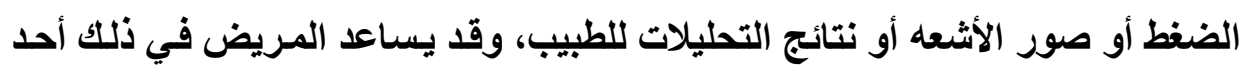

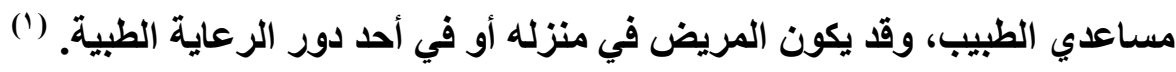
وبناءً على هذه المعلومات المرسلة للطبيب، يستطيع أن يقرر مدى وجود تقدم

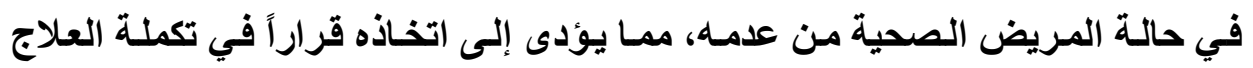

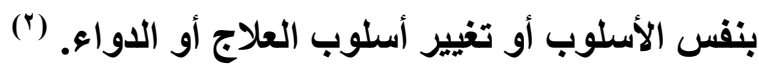
وممـا لا شـك فيسه أن تكنولوجيا المعلومـات تسمح بإرسـال كثير من المعلومـات

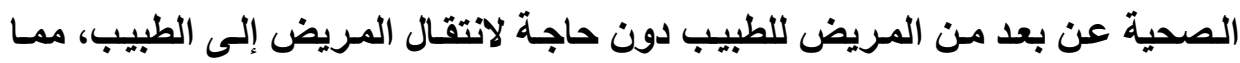

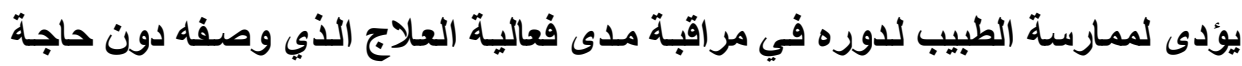

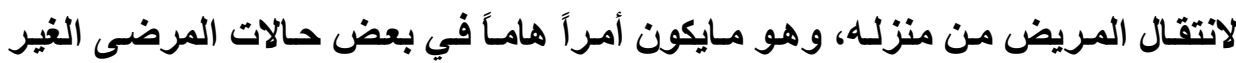
قادرين على الحركة أو كبار السن.

وتتطور التطبيقات التكنولوجية التي تساعد الأطباء في العنايـة الطبية عن بعد بشكل كبير، فقد طورت إحدى شركات الأجهزة الطبية تقنية جديدة تتيح نقل البيانـات

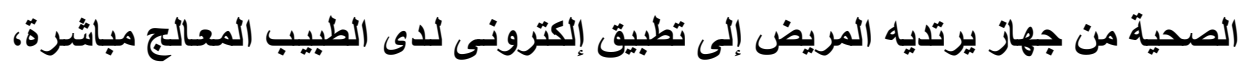

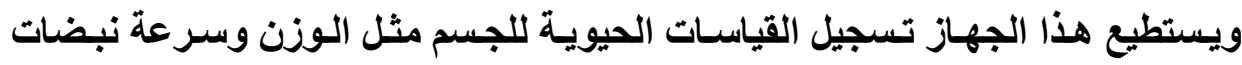
القلب وضغط الدم ونقلها للطبيب مباشرة من خلال تطبيق إلكتروني، وتعود هذه التقنية

(1) Jean-Louis ARNÉ, Éthique: jurisprudence et télémédecine, Op.cit.

(2) Marcel POCHARD et Autres, Vade-mécum télémédecine, Op.cit, P 10. 
عدد خاص بالمؤتمر الدولى السنوى العشرون أ. د/ سامح عبد الواحد التهامى

بالفائدة على المصابين بأمر اض مزمنة مثل ارتفاع ضغط الدام ويحتاجون إلى توصيل المعلومات بثكل مستمر إلى الطبيب حتى يستطيع إدخال أي تعديلات في أسلوب العلاج

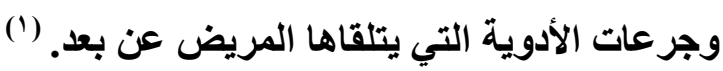

فالهدف الرئيسي للعناية الطبية عن بعد هو تجنيب المريض عنـاء الذهاب إلى

الطبيب من أجل المتابعة بعد تلقى العلاج، حيث يكفي التواصل عن بعدئ بعد مـع الطبيب وإرسال القياسـات المطلوبـة والمعلومـات، بحيث يستطيع الطبيب أن يقرر مدى نجاح

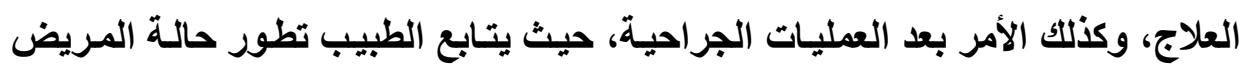
عن بعد، بحيث لاينتقل المريض إلا عند الحاجة.

ويري البعض أن العناية الطبية عن بعد هي أكثر صور العمل الطبي عن بعد

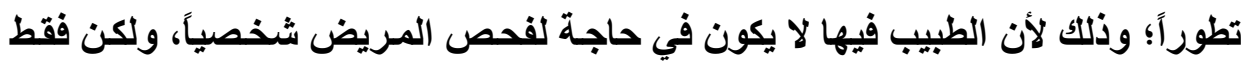
الاطمئنان على سير العلاج بشكل طبيعي، ولذلك ستلعب العنايـة الطبية عن بعد دون دوراً

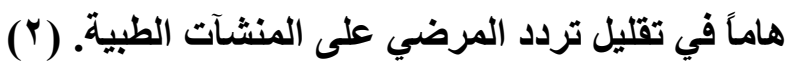

(1) تطبيق يوظف تقتية العلاج عن بعد يُمكّن الأطباء من مراقبة صحة المرضى وهم في منازلهم، خبر

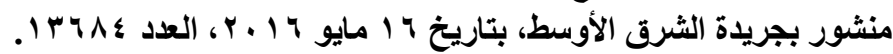

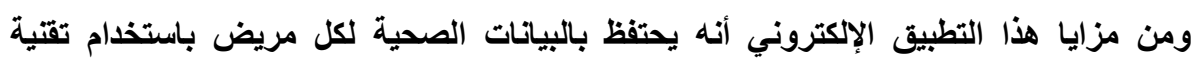

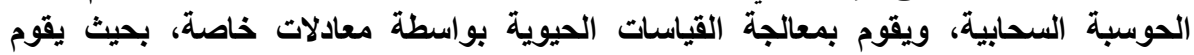
بتصنيف حالة كل مريض حسب درجة خطورتها أو استقرار ها عن طريق الفئ إندارات لونية، ثم إخطار الطبيب بثكل مباشر إذا ما استدعت الضرورة

(2) Philippe BURNEL, la télésanté, en dossier: Quelle santé à domicile pour demain ?: Enjeux et perspectives, Fédération des prestataires de santé à domicile, France, Janvier 2015, P 17. 
عدد خاص بالمؤتمر الدولى السنوى العشرون أ. د/ سامح عبد الواحد التهامى

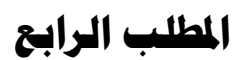

\section{المباعدة الطبية عن بعد}

عرفت المادة (R. 6316-1-4) من قانون الصحة العامـة المساعدة الطبية عن

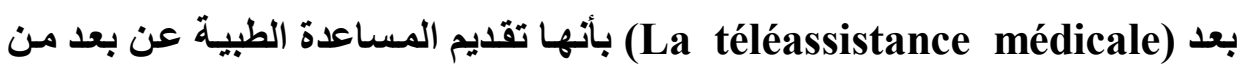
الطبيب لمساعد الطبيب أثناء قيامه بأي عمل من أعمال الرعاية الصحية للمريض.

فهذه الصورة من صور العلاج عن بعد هي علاقة بين الطبيب ومساعد الطبيب

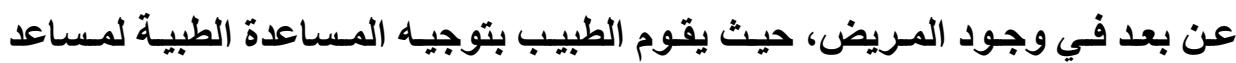
الطبيب أثناء قيامه بعمل طبي للمريض، وبالتـالي فعلاقة الطبيب بالمريض هنـا تكون علاقة غير مباشرة يتوسطها مساعد الطبيب. (1) والجدير بالذكر أن المشرع في نص المادة (R-1-6316 . 20 من قانون الصحة العامة عندما تناول العمل الطبي الذي يساعد الطبيب فيه معاونه عن بعد، لم يحدد عملًا

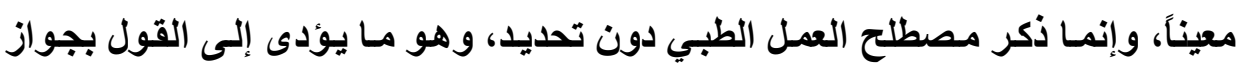

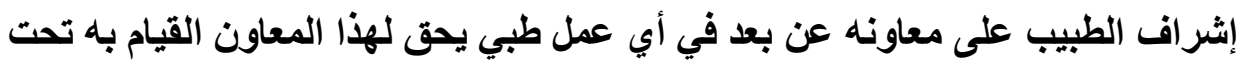
إثراف الطبيب، فهذا العمل قد يكون مجرد عمل من أعمال متابعة المريض بعد بعد القيام بجراحة أو أثناء فترة النقاهة أو حتى عمل علاجى بسيط. ويجب أن يُلاحظ هنا أن هذه الصورة تختلف عن (تبادل الخبرة الطبية عن بعد)؛

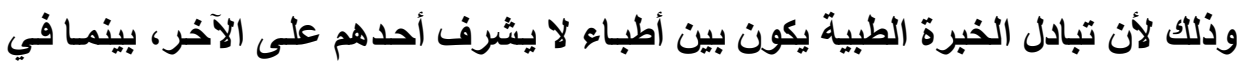

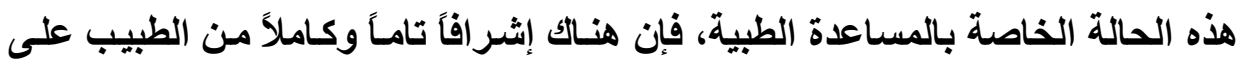

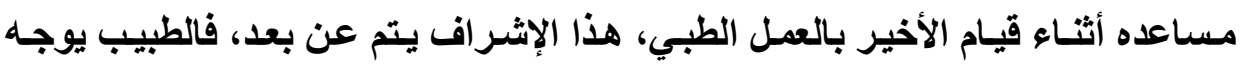
مساعده ويراقبه ويساعده طيلة فترة قيامه بالعمل الطبي مع المريض.

(1) Nicolas GIRAUDEAU, Op.cit, P 107.

(2) Marcel POCHARD et Autres, Vade-mécum télémédecine, Op.cit, P 11.

07. مجلت البحوث القانونيت والإقتصاديت 
عدد خاص بالمؤتمر الدولى السنوى العشرون أ. د/ سامح عبد الواحد التهامى

وتطبيقا لذلك يوجد الآن مـا يعرف بالعنايـة المركزة عن بعد، وهي عبارة عن

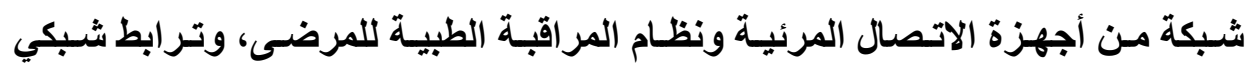

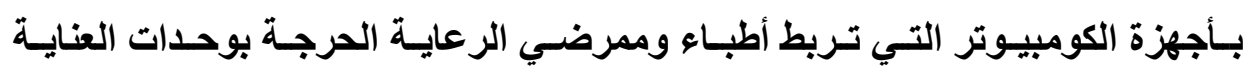

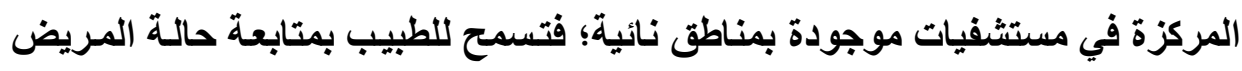

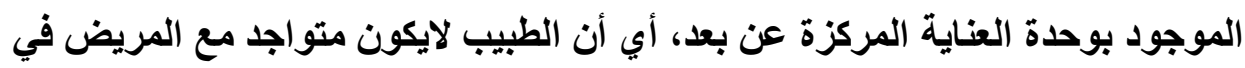

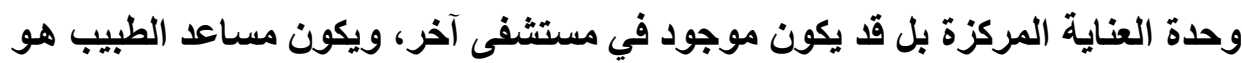

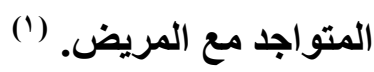

الإطلب الخاهمس

\section{الاستجابة الطبية عن بعد}

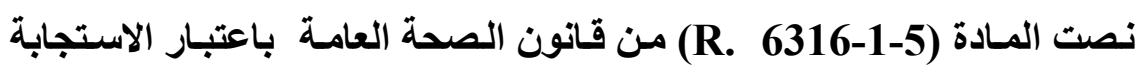

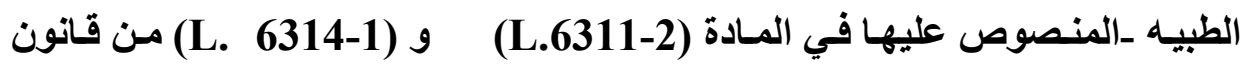
الصحة العامة_عملاً طبيًّا عن بعد، مما يعني جواز قيـام الطبيب بالاستجابة الطبية عن الطن

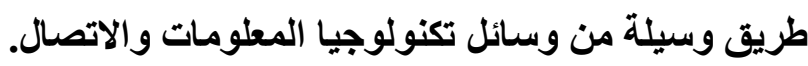

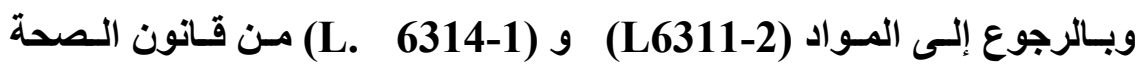

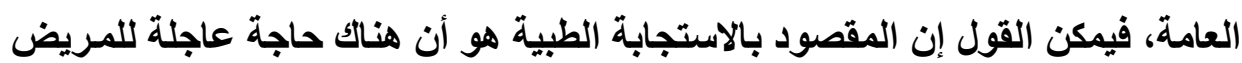

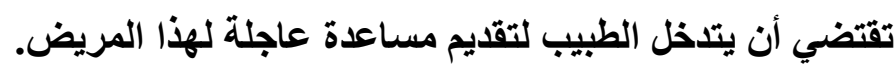

والمقصود بأن تتم الاستجابة الطبية عن بعد، أن الحالة العاجلة لهذا المريض

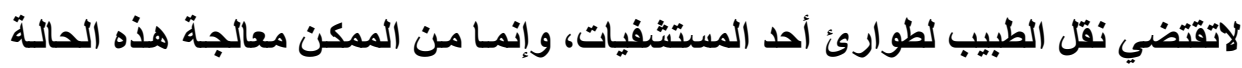

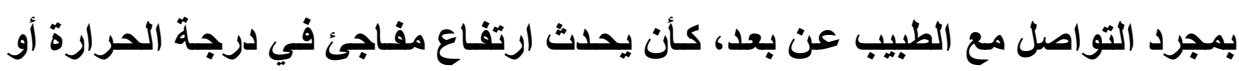

(1) Sajeesh KUMAR and others, Tele-ICU: Efficacy and Cost-Effectiveness Approach of Remotely Managing the Critical Care, Open Med Inform J. 2013; 7: 24-29. 
عدد خاص بالمؤتمر الدولى السنوى العشرون أ. د/ سامح عبد الواحد التهامى

ضغط الام، فمجرد إخبار الطبيب عن بعد بلرجة الحرارة أو قياس الضغط، سبيتطيع

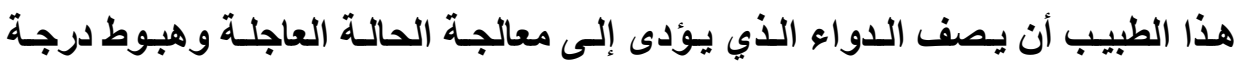

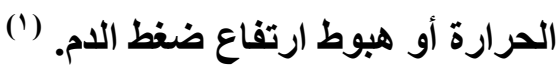

وتقوم الاستجابة الطبيـة عن بعد على محادثة بين المـريض أو أحـ مرافقيـه

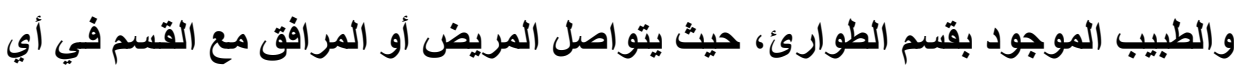
وقت من اليوم ويتحدث للطبيب عن الحالة الطارئة، بحيث يقوم الطبيب بوصف الحل

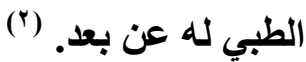

(1) Michaël Balavoine, télémédecine: L'exemple valaisan , Art disponible sur: https://www.planetesante.ch, La date de mise en ligne est:14/03/2011.

(2) Patricio Costa LOUREIRO, Télésanté: télémédecine en pharmacie et télépharmacie : les nouvelles technologies de l'information et de la communication au service de la santé, Thèse pour l'obtention du Diplôme d'Etat de docteur en pharmacie, Univ de Bordeaux, 2016, p 22. 
عدد خاص بالمؤتمر الدولى السنوى العشرون أ. د/ ساميح عبد الواحد التهامى

النصل الثاني

الضوابط القانونية للعهمل الطببي عن بعد

تمهي⿻ وتقسيم:

الأصل أن العمل الطبي عن بعد هو عمل طبي يخضع لذات القواعد القانونية

الواردة في التشريعات الطبية، سواء مايتعلق بقواعد ممارسة العمل الطبي أو التزامات

الطبيب ومسؤوليته عن العمل الطبي، أو مايتعلق بحقوق المريض، فالعمل الطبي عن

بعد ليس له قواعد قانونية خاصة به فيما يتعلق بالممارسة الطبية القنية. (1)

ولكن نظراً لأن العمل الطبي عن بعد هو صورة حديثة من صور العمل الطبي

التي تتم دون اللقاء المـادي في مكان واحد بين الطبيب والمريض، وإنمـا يتم اللقاء

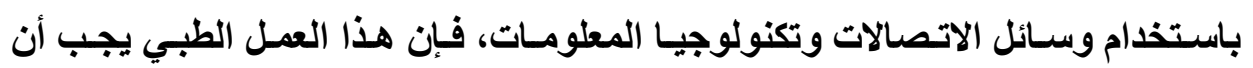
يحيطه بعض الضوابط القانونية التي تضمن أن يتم هذا العمل الطبي بصورة صحيحة ولا يؤدى للإضرار بالمريض الذي لجأ لهذه الوسيلة الحديثة.

و هذه الضوابط نص عليها قانون الصحة العامة الفرنسي بعد إضافة فصل كامل

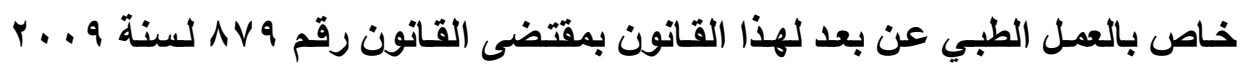

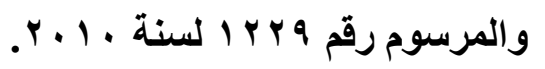

(1) Anastasie KERLUEN, La télémédecine en question: quand la médecine utilise les nouvelles technologies de l'information, Art disponible sur: www.blog-dmi.com, la date de mise en ligne est: 29 janvier 2011. 
عدد خاص بالمؤتمر الدولى السنوى العشرون أ. د/ سامـع عبد الواحد التهامى

وهذه الضوابط تتمحور حول ثلاثة محاور: أولها هو من يقوم بممارسـة العمل الطبي عن بعد، وثانيها هو المريض، وثالثها هو النظام المعلومـاتى المستخدم لإجراء

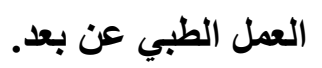
وبالتالى فسوف نقوم بتقسيم هذا الفصل إلى: المبحث الأول: شروط ممارس العمل الطبي عن بعد. المبحث الثاني: حماية المريض في العمل الطبي عن بعد. المبحث الثالث: كفاءة النظام المعلوماتي. 
عدد خاص بالمؤتمر الدولى السنوى العشرون أ. د/ سامح عبد الواحد التهامى

\section{المبحث الأول}

\section{شروط همارس العمل الطبي عن بعد}

نص قـانون الصحة العامسة الفرنسي في المـادة (L6316-1) على وجـوب أن

يمسارس بالعمل الطبـي عن بعد شـخص مـرخص لـه بممارسـة العمـل الطبـي التقليدي، فلايجوز مزاولة العمل الطبي عن بعد من قبل شخص غير مرخص لـه بممارسـة العمل الطبي في شكله التقليدي، وإلا كان مرتكباً لجريمة مزاولة العمل الطبي بدون ترخيص. وقانون الصحة العامة الفرنسي يهدف من ذلك إلى ألا يقل مستوى جودة العمل الطبي عن بعد عن مستوى جـودة العمـل الطبي التقليدي، ممـا يمكن المـريض مـن الحصول على الخدمة الطبية عن بعد بنفس مستوى الخدمة الطبية العادية.

ووفقاً لقـانون الصحة العامـة الفرنسي، فِإن مـن يقوم بممارسـة العمـل الطبـي بصفة عامة هم الطبيب والمعالج النفسي وطبيب الأسنان فضلا عن المساعدين مثل

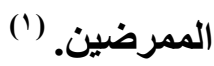

وللتلك فقد أجـازت المـادة (R-16 6316) من قـانون الصحة العامـة الفرنسي

للطبيب والمعالج النفسي وطبيب الأسنان ومساعديهم ممارسة العمل الطبي عن بعد. وقد نـصت المـادة (R.6316-9) مـن قـانون الصحة العامـة على وجوب تمتع الأطباء أو المعالجين النفيين أو طبيب الأسنان أو مساعديهم الذين يمارسون العمل

(1) Anne-Sophie MAZEIRAT, La télémédecine: nouvelle pratique médicale, Art disponible sur: www.prevention.sham.fr , La date de mise en ligne est: 7/04/2011. 
عدد خاص بالمؤتمر الدولى السنوى العشرون أ. د/ سامح عبد الواحد التهامى

الطبي عن بعد بالمعرفـة والمهـارات التقنيـة التي تسمح لهم باسـتخدام البرمجيـات الخاصة بالعمل الطبي عن بعد.

ويرى جاتب من الفقه أن هذا الشرط يتطلب أن يكون الطبيب أو المعالج النفسي أو طبيب الأسنان أو مساعديهم قد تلقى تدريباً خاصاً بكيفية ممارسـة العمل الطبي عن بعد، أو يكون قد درس مقرراً خاصـاً بالعمل الطبي عن بعد أثنـاء دراسته الطبية في الجامعه، وهو ما تقدمه كليات الطب بالجامعات الفرنسية الآن من تدريس مقرر للعمل الطبي عن بعد للطلاب يتضمن الجوانب التقنية للعمل الطبي عن بعد، وتدريب الطلاب عليها فضلاً عن تناول الجوانب القانونية لهذا العمل الطبي. (1) فتطلب قانون الصحة العامة أن يمتلك الطبيب المهارات التقنية للعمل الطبي عن بعد هو شرط قانوني يجب توافره فيمن يمارس العمل الطبي عن بعد ممـا يقتضي على أقل تقدير أن يتلقى هذا الطبيب تدريباً معتمداً في هذا الثأن. وقد تم إنشاء الجمعية الوطنية للعمل الطبي عن بعد بفرنسا، حيث تقدم هذه

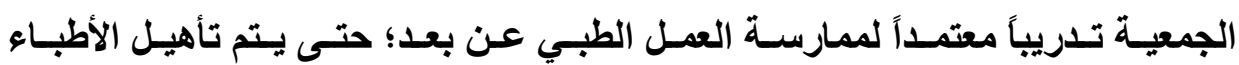
والمعـالجين النفسيين وأطباء الأسنان ومساعديهم لتحقيق شرط الكفـاءه الذي تطلبه قانون الصحة العامة. ويرى رأي في الفقه أن المصطلح الذي استخدمه المشرع في قانون الصحة العامـه هو مصطلح (المعرفـه) وهو مـا يعنى أن الطبيب أو المعـالج النفسي أو طبيب الأسنان أو مساعديهم ملتزم بالتدريب المستمر على التطور التقني المستمر في مجـال

(1) Nicolas GIRAUDEAU, Op.cit, P 26.

(Y) يمكن الاطلاع على أنثطة الجمعية على الموقع الأكتروني: fr.antel.www. 
عد عاص بالمؤتمر الدولى السنوى العشرون أ.د/ سامح عبد الواحد التهامى

العمل الطبي عن بعد؛ وذلك لأن ممارسـة العمل الطبي عن بعد مرتبطة بتكنولوجيا

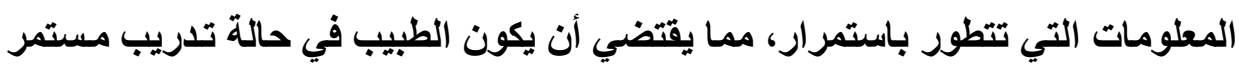

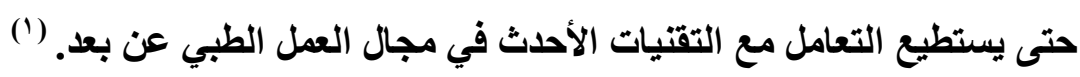

ويرى رأي آخر في الفقه أن تدريب الطبيب أو المعالج النفسي أو طبيب الأسنان

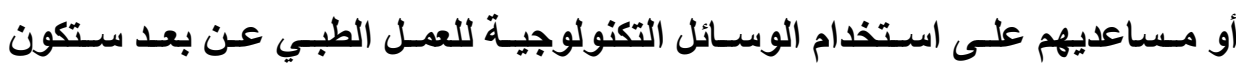
مسؤولية الفني المختص بتكنولوجيا المعلومـات في المنشأة الطبية ممـا يلقى التزامـاً على عاتق هذا القني بتدريب العاملين في الكادر الطبي على أي تحديث في وسائل العمل

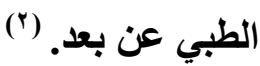

(1) Nicolas GIRAUDEAU, Op.cit, P 45.

(2) Patricio Costa LOUREIRO, Télésanté: télémédecine en pharmacie et télépharmacie, Op.cit, p 52. 
عدد خاص بالمؤتمر الدولى السنوى العشرون أ. د/ سامح عبد الواحد التهامى

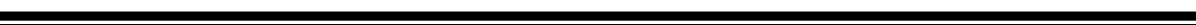


عدد خاص بالمؤتمر الدولى السنوى العشرون أ. د/ سامح عبد الواحد التهامى

\section{المبحث الثاني}

\section{هماية المريض في العمل الطبـي عن بمد}

مما لا شك فيه أن شفاء المريض وتخفيف آلامه هو الهذف النهائي للعمل الطبي

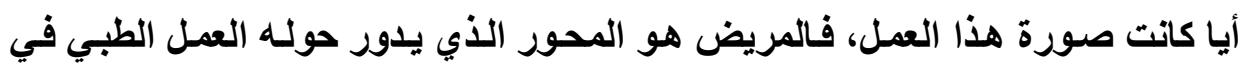
جميع صوره، وهو الذي يتم تقديم الخدمـه الطبيه لـه في سبيل تحقيق شفائه، ولذلك ألقت القوانين المختلفة بكثير من الالتزامـات على عاتق الطبيب في مواجهة المريض

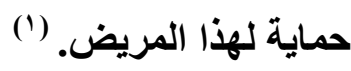
والعمل الطبي عن بعد لا يختلف عن العمل الطبي العادي في هذا الهدف، فهو أيضاً يهدف لتحقيق مصلحة المريض، بـل إن هذه الصورة الحديثة مـن صور العمل الطبي كان مبعثها الأساسي هو التسريل على المريض في تلقي الخدمة الطبية وسرعة تقديم هذه الخدمة لهه والمساواة بين جميع المرضسي في كل الأمساكن في تلقي الخدمـة

$$
\text { الطبية بذات الجودة. }
$$

وحماية المريض هي غاية تهدف إليها التشريعات التي تنظم العمل الطبي؛ لأن المريض يكون طرفاً ضعيفاً في العلاقة القانونية مع الطبيب، وحمايـة هذا المريض في العمل الطبي عن بعد أوجب، نظراً لعدم وجود العلاقة المباشرة وجها لوجه بين الطبيب والمريض، وإنما تكون هذه العلاقة عن طريق وسائل الاتصال الحديثة.

(1) لمزيد من التفاصيل عن التزامات الطبيب نحو المريض، أنظر: محسن عبد الحميد البيه، التزامات

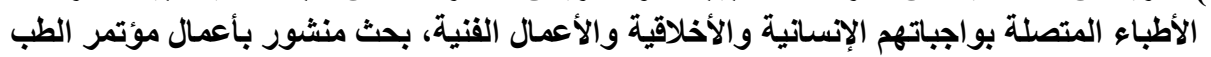

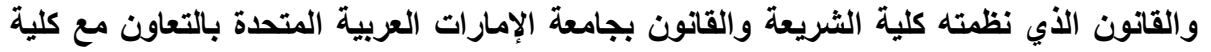

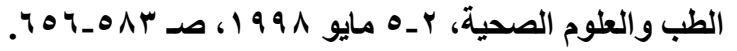


عدد خاص بالمؤتمر الدولى السنوى العشرون أ. د/ سامح عبد الواحد التهامى

وقد ذكرنـا سـابقًا أن المشرع الفرنسي قد أدخل بعض التعديلات على قانون

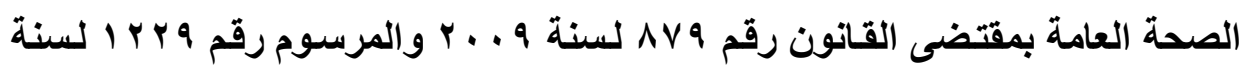

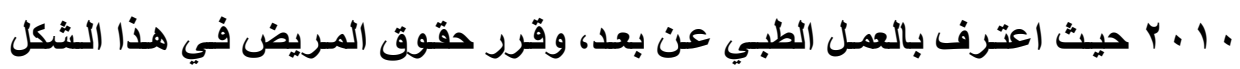
الحديث من أشكال العمل الطبي.

ويمكن القول إن المريض الذي يتلقى العمل الطبي عن بعد يتمتع بذات الحقوق

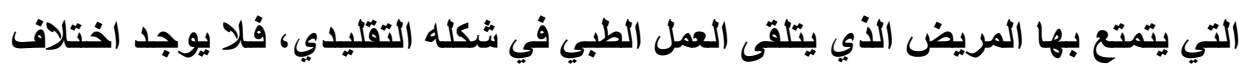

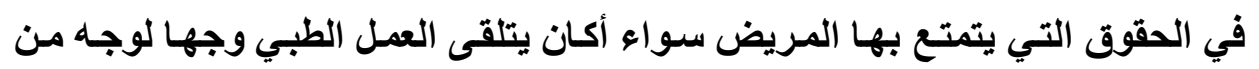
الطبيب أو يتلقى العمل الطبي من الطبيب عن بعد.

إلا إن دخول الوسيلة التكنولوجية في العلاقة بين الطبيب والمريض قد ألقى بظلالهـ على بعض حقوق المريض، وهي حق المريض في حماية خصوصيته أثناء القيام بالعمل الطبي عن بعد، وحقه في إبداء الرضاء المستتير على الأعمال الطبية التي تتم عن بعد.

فالحقوق المقررة للمريض في العمل الطبي التقليدي هي ذاتها الحقوق المقررة

له في العمل الطبي عن بعد مع الأخذ في الاعتبار طبيعة العمل الطبي عن بعد، بحيث تتطور بعض هذه الحقوق في العمل الطبي عن بعد لتلائم هذه الصورة الحديثة من صور العمل الطبي، ولذلك فقد اشترط قـانون الصحة العامـة الفرنسي ضـمان الكفـاءة التقنية للمريض الأي يخضع للعمل الطبي عن بعد. (1)

(1) Jean-Louis ARNÉ, Éthique: jurisprudence et télémédecine, Op.cit.

مج مجلت البحوث القانونيت والإقتصاديت 
عدد خاص بالمؤتمر الدولى السنوى العشرون أ. د/ سامح عبد الواحد التهامى

وبالتالي سنتناول في هذا المبحث القواعد الخاصـة بحمايـة المريض في العمل

الطبـي عن بعد، حيث سـنتناول ضـمان الكفــاءة التقنيـة للمـريض، ثم نتـــاول حمايـة

خصوصيته وأخير ا نتناول حماية رضائه.

حتى نتناول هذه النقاط، فسوف نقوم بتقسيم هذا المبحث إلى:

المطلب الأول: ضمان الكفاءة التقتية للمريض.

المطلب الثاني: حماية خصوصية المريض.

المطلب الثالث: حماية رضاء المريض.

\section{المطلب الأول}

\section{ضشان الكفاءة التقنية للهمريض}

لقد أدى ظهور شبكة الإنترنت إلى أن المريض قد أصبح لـه المزيد من المعرفة الطبية وذلك بالدخول على المواقع الطبية وتبادل المعلومات مع غيره من المرضى عبر مواقع التواصل الاجتماعي، وقد أدى دخول تكنولوجيا المعلومات فى الخدمات الصحية إلى ظهور مصطلح (المريض عن بعد)، فهذه التكنولوجيا أعطت بُعداً جديداً لمركز المريض فى العمل الطبي؛ حيث أنه أصبح لـه بعض الدور الإيجابي في بعض صور

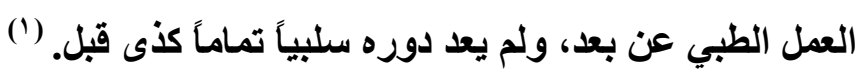
وهذا الدور يختلف بحسب كل صورة من صور العمل الطبي عن بعد، ففي مجال تبـادل الخبرات عن بعد (La téléexpertise)، لا يكون للمـريض أي دور حيث إن ئن تبادل الخبرات يتم بين الطبيب المعالج للمريض وأي طبيب آخر، وفي مجال المساعدة

(1) Nicolas GIRAUDEAU, Op.cit, P 52-53. 
عدد خاص بالمؤتمر الدولى السنوى العشرون أ. د/ سامح عبد الواحد التهامى

الطبية عن بعد (La téléassistance médicale)، لا يكون للمريض أي دور؛ لأن

المساعدة الطبية تقدم من أحد الأطباء إلى مساعد الطبيب القائم بعلاج المريض. (')

أما في مجال الاستشارة الطبية عن بعد، فإن المريض يلعب دوراً أكثر إيجابية،

إذ يتو اصل مع الطبيب عبر وسيلة من وسـائل التواصل الحديثة ممـا يقتضي أن يكون على علم ودراية باستخدام وسيلة التواصل حتى يتلقى الاستثـارة بشكل سليم، كمـا أنـه يصف للطبيب حالته عن بعد، كما يقوم المريض بتوجيه الكاميرا على المناطق المصابة حتى يراها الطبيب جيداً، ويبنى الطبيب قراره في تثخيص المرض ووصف العلاج بناءً على ذلك، فلا يكفى أن يكون المريض قادراً على استخدام وسيلة التواصل لشرح حالته للطبيب، بل يجب أن يعطيه وصفاً دقيقاً وبيانات كاملة، فالعلاقة بين الطبيب والمريض في هذه الحالة هي علاقة طبية تقنية.

وفى العنايـة الطبيـة عن بعد، يلعب المريض دوراً إيجابياً، حيث يصف حالته

للطبيب أثناء تلقيه العلاج أو بعد العمل الجراحي، وقد يفحصه الطبيب عن بعد أو يرى مكان العمل الجراحي، وكذلك الأمر في الاستجابة الطبية عن بعد، التي تقتضي من المريض وصف الحالة الطارئة للطبيب عن بعد.

فهذا الدور الإيجابي الذي يلعبه المريض في العمل الطبي عن بعد يتطلب أن يتوافر في المريض بعض المهارات والمؤهلات التي تجعله قادراً على لعب هذا الدور، بحيث يكون المريض قادراً على استخدام الأدوات التي تستخدم في العمل الطبي عن بعد، أي قادرا على استخدام الوسائل التكنولوجية للعمل الطبي عن بعد.

(1) Ibid, P 55.

(2) Patricio Costa LOUREIRO, Télésanté: télémédecine en pharmacie et télépharmacie, Op.cit, p 34. 
عدد خاص بالمؤتمر الدولى السنوى العشرون أ. د/ سامح عبد الواحد التهامى

فمطلوب مستوى معين من الكفاءة التقنية في المريض من أجل الاستخدام الآمن

لوسائل الاتصال الحديثة وما يتصل بها من الأدوات الطبية الرقمية، حيث سيتعين على

المريض تعلمها إذا كان جاهلاً بها.

ولذلك فقد نصت المادة (R-6316-3 من قانون الصحة العامة على أنسه في

العمل الطبي عن بعد، إذا تطلب الأمر، فيجب أن يتم تدريب المريض على استخدام

وسيلة العمل الطبي عن بعد قبل البدء في هذا العمل الطبي.

ويترتب على ذلك أن الطبيب قبل القيام ببدء العمل الطبي مـع المريض يجب أن

يتأكد من قرته على استخدام وسيلة العمل الطبي عن بعد بشكل مناسب، فبإن لم يكن قادراً على ذلك فلا يبدأ العمل الطبي معه قبل تلقى هذا المريض التدريب المناسب الذي لـي يسمح لـه بتلقي العمل الطبي عن بعد، وهذا التدريب قد يمنحهـ أحد معاونى الطبيب

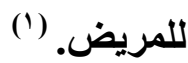

ولكن هذا سيُلقي بعبعٍ كبير على أعضاء الفريق الطبي، ولذلك يقترح رأي في

الفقه بأن يتم تدريب المرضى على استخدام أدوات العمل الطبي عن بعد من قبل طلاب

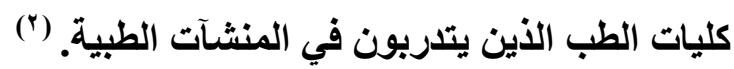

ويرى رأي في الفقه أن المريض بذلك سيتغير مركزه من مجرد مطيع لأوامر

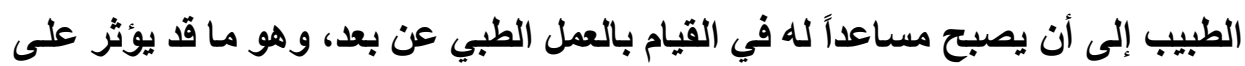

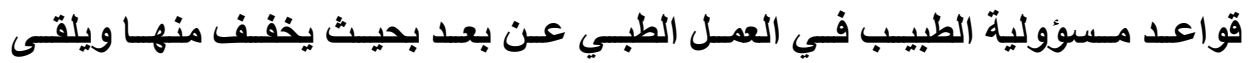

(1) Lina PELLITERRI, les aspects réglementaires de la télémédecine, en (Télémédecine : état des lieux, perspectives et opportunités): Compterendu de conférence, Eurasanté, Jeudi 09 février 2012.

(2) Nicolas GIRAUDEAU, Op.cit, P 128. 
عدد خاص بالمؤتمر الدولى السنوى العشرون أ. د/ سامح عبد الواحد التهامى

ببعض المسؤولية على المريض في حالة خطئه في استخدام وسيلة العمل الطبي عن بعد. (1)

\section{الاطباب الثاني}

\section{هماية خصوصية المريض}

إن احترام خصوصية المريض هو أمر واجب في كل صور العمل الطبي، فحماية

البيانـات الشخصية للمـريض هـو أمـر لازم سـواء كانـت هذه البيانـات متعلقـه بحالتـهـ

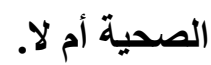

ومما لا شك فيه أن الطبيب أو المنشأة الطبية عندما تتعامل مـع المريض لتقديم

العمل الطبي عن بعد، فسوف تقوم بتجميع البيانـات الشخصية لهذا المريض وحفظها بعد عمل ملف طبي إلكتروني له، هذا الملف سيحتوي على كل مـايتعلق بحالة المريض الصحية والتي تعد من أهم صور البياتات الشخصية.

وحيث إن العمل الطبي عن بعد يتم باستخدام تكنولوجيا المعلومات، فإنه يتضمن

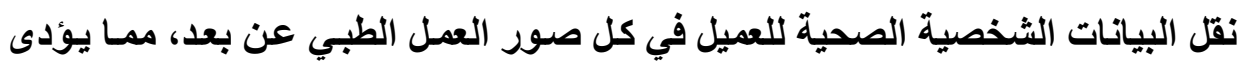
إلـى القول بـأن هذه البيانـات في حاجـة إلى حمايـة أكبر؛ نظراً للمخـاطر التي تحيط بتكنولوجيا المعلومات بصفة عامة، ونظراً لخطورة هذه البيانات الصحية بصفة خاصة،

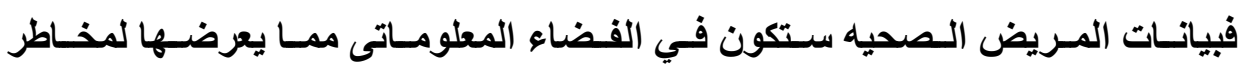

كبيرة. (r)

(1) Claire DEBOST, L'appréhension juridique de la relation de soin au prisme des nouvelles technologies, Op.cit.

(2) Anne BEAUFORT et Alice PHILIPPOT, Innovation médicale : le corps ou l'objet ?, Op.cit. 
عدد خاص بالمؤتمر الدولى السنوى العشرون أ. د/ سامع عبد الواحد التهامى

فالطبيب الذي يمسارس العمل الطبي عن بعد يحق لـهله بمقتضى نـص المـادة

(R.6316-3) من قانون الصحة العامة أن ياخل على الملف الإكترونى الذى يتضمن

البيانات الصحية للمريض حتى يستطيع أن يقوم بالعمل الطبي عن بعد، ويستطيع أن يتبادل هذه البيانات مع غيره من الأطباء بعد موافقة المريض.

ولذلك كان من الواجب وضع حمايـة قانونية لتلك البيانـات الثخصية التي يتم

تجميعها وتداولها أثناء مراحل تقديم العمل الطبي عن بعد في كل صورة من صوره.

وسوف نتناول الحماية القانونية لخصوصية المريض في العمل الطبي عن بعد

من خلال تقسيم هذا المطلب إلى فرعين، حيث سنتناول في الفرع الأول ضوابط معالجة البيانات الثخصية للمريض، وسنتناول في الفرع الثاني الالتزام بالحفـاظ على سرية البيانات الثخصية للمريض.

\section{الفرع الأول}

\section{ضوابط همالجة البيانات الشخصية للمريض}

نصت المـادة (R-10-6316) مسن قـانون الصحة العامـة، على أن المنشآت الصحية والأفراد التي تقوم بالعمل الطبي عن بعد يجب أن تتأكد من أن البرمجيات التي تستخدمها في تقديم العمل الطبـي عن بعد تحترم القواعد الخاصـة بحمايـة البيانـات الثخصية للمريض والمنصوص عليها في المـادة (L.111-8) مـن قانون الصحة العامة.

وبالرجوع لنص المادة (L.1111-8)، سنجد أنها نصت على أن أي (منشأة أو شخص) يعمل في المجال الطبي يقوم بتجميع البيانات الشخصية للمرضى يجب أن يتقيد 
عدد خاص بالمؤتمر الدولى السنوى العشرون أ. د/ سامح عبد الواحد التهامى

بجميع قواعد حمايـة البيانـات الشخـصية المنـصوص عليهـا في قـانون المعلوماتيـة وحماية البياتات والحريات. (')

وأهم هذه القواعد أن يتم الحصول على موافقة اللجنة القومية للحريـات على

إنشاء قواعد بيانات شخصية للمرضى الأين يتم تقديم العمل الطبي لهم عن بعد، فلا يتم

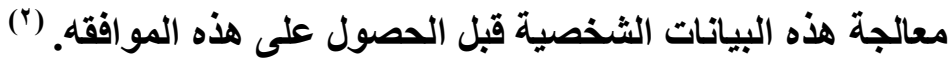

كمـا أنـه تطبيقاً لنص المـادة السـابعة مـن قـانون المعلوماتيـة وحمايـة البيانـات

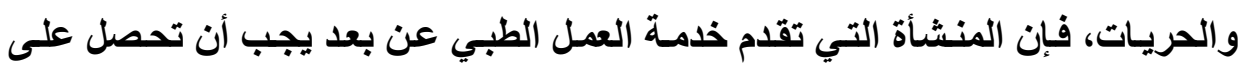

رضاء المريض قبل الحصول على بياناته الثخصية وقبل القيام بأي إجراء خاص بهذه بذه بهات

البيانات، وذلك بعد إعلام المريض بكل الإجراءات التي ستقوم بها في هذه البيانات.

وتطبيقا للمـادة r r و q مـن نفس القانون، يجب على المنشأة الطبية إعلام

المريض بالبيانات الثخصية التي سوف يتم تجميعها والغرض من تجميع هذه البيانات،

وذلك قبل القيام بتجميعها وقبل إبداء المريض لرضائه بتجميع تلك البيانات، حتى يكون

رضاؤه مستنيراً.

وتطبيقاً للمادة السادسة من ذات القانون، يجب أن تقتصر المنشأة الطبية على

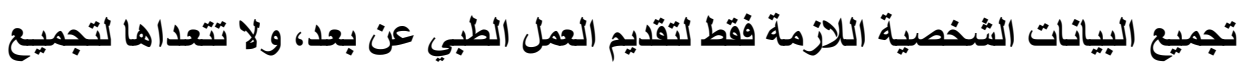

بيانات أخرى ليست لها علاقة بالحالة الصحية للمريض، حتى ولو وافق المريض على ولى ولات

تجميع هذه البيانات.

(1) Loi $\mathrm{n}^{\circ} 78-17$ du 6 janvier 1978 relative à l'informatique, aux fichiers et aux libertés, modifeé par loi $n^{\circ}$ 2016-1321 du 7 octobre 2016 pour une République numérique, JORF, $n^{\circ} 0235$ du 8 octobre 2016, texte $n^{\circ} 1$.

(2) Nicolas SAMARCQ et Sébastien BRIOIS, Télémédecine : quel cadre juridique, Op.cit. 
عدد خاص بالمؤتمر الدولى السنوى العشرون أ. د/ سامع عبد الواحد التهامى

وتطبيقاً للمـادة السادسة من ذات القـانون، فبإن المنشأة الطبية يجب أن تلتزم

بالغرض الذي من أجله قامت بتجميع هذه البيانات، وهو تسهيل العمل الطبي عن بعد،

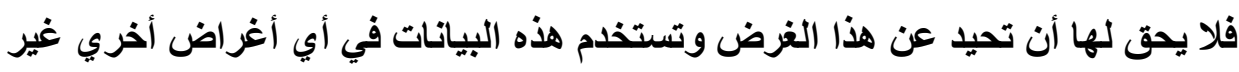
هذا الغرض الذي وافق عليه المـريض، كمـا يجب ألا تحتفظ بهذه البيانـات إلا للمـدة اللازمة لتقديم العمل الطبي عن بعد، فإذا انتهت علاقة المريض بالمنشأة الطبية، فيجب على هذه المنشأة أن تقوم بمسح بيانات المريض.

وتطبيقاً لنص المادة ء ب من ذات القانون، تلتزم المنشأة الطبية التي تقلم العمل

الطبـي عن بعد أن تقوم بتـأمين قواعد البيانـات الثخصية للمرضسى، وتحسافظ على سريتها، وتحميها من خطر السرقة أو التدمير أو الاختراق من قبل الهاكر على شبكة

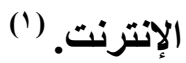

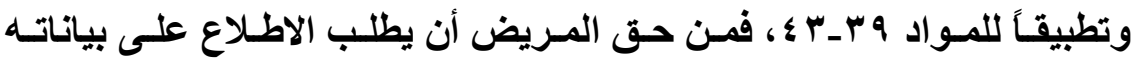

الثخصية المحفوظه عند المنشأة الطبية ويحصل على صورة منها، كمـا يحق لله طلب

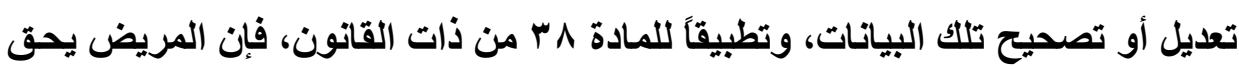

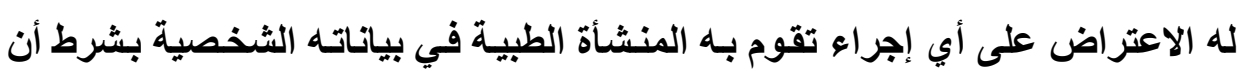

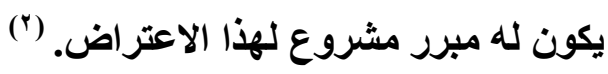

(1) Stéphane ASTIER, Télémédecine et Télésurveillance médicale :quelles contraintes juridiques ?, Art disponible sur: www.haas-avocats.com, La date de mise en ligne est: 22 Janvier 2014.

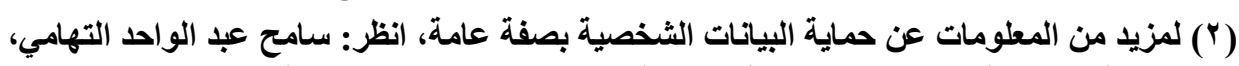

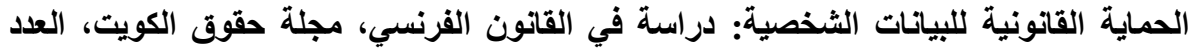

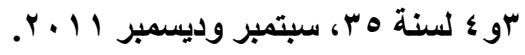


عدد خاص بالمؤتمر الدولى السنوى العشرون أ. د/ سامح عبد الواحد التهامى

وبالتالي فإن أي منشأة أو طبيب يقوم بالعمل الطبي عن بعد يجب أن يتأكد من

أن البرمجيات المستخدمة في تقديم العمل الطبي عن بعد تحترم قواعد حمايـة البيانـات الثخصية المنصوص عليها في قانون المعلوماتية وحماية البيانات والحريات من حيث قواعد تجميع هذه البيانات أو قواعد معالجتها، وأن تقوم بالحصول على موافقة اللجنة القومية للحريـات على إنشاء قواعد بيانـات شخصية للمرضى الذين يتم تقديم العمل مل مل (الطبي لهم عن بعد. (1)

فقيام المنشأة أو الطبيب في عيادته بتقديم العمل الطبي من خلال موقع الكتروني على شبكة الإنترنـت يقتضي مـن مقدم العمـل الحصول على مواققة اللجنـة القوميـة للحريـات على هذا الموقع؛ لأنـه سيتضمن معالجـة للبيانـات الشخصية للمرضس، وأن يتقيد بكل القواعد الواردة في قانون المعلوماتية وحماية البيانات والحريات. (r)

\section{الفنرع الثثاني}

\section{الالتزام بالهفاظ على سرية البيانات الشخصية للمريض}

نصت المادة (• r) من لائحة آداب مهنة الطب البشري على التزام الطبيب بعدم

إفشاء أسرار مريضه التي اطلـع عليها بحكم مهنته إلا إذا كـان ذلك بنـاء على قرار

قضائي أو في حالـة إمكان وقوع ضـرر جسيم ومتيقن يصيب الغير أو في الحساتات

الأخرى التي يحددها القانون.

(1) Nathalie BESLAY, La conduite juridique d'un projet de télémédecine, Art disponible sur: http://www.magazine-decideurs.com/news/laconduite-juridique-d-un-projet-de-telemedecine, La date de mise en ligne est: 18-11-2014.

(2) Jesus CARDENAS, Des avancées dans la pratique de la médecine à distance, Op.cit. 
عدد خاص بالمؤتمر الدولى السنوى العشـرون أ. د س سامع عبد الواحد التهامى

فالطبيب ملتزم بعدم إفشاء أي معلومات تصل إلى علمه أيا كانت طبيعتها تتعلق

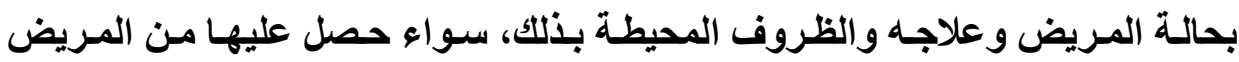
نفسه أو علم بها أثناء أو بمناسبة أو بسبب ممارسـة مهنته، مـالم يسمح لـه القانون إفثاء هذه الأسرار في حالات معينة. (1) ويترتب على ذلك أن الطبيب القائم بالعمل الطبي عن بعد عندما يقوم بـالاطلاع على البيانـات الصحية الخاصـة بـالمريض يصبح ملتزمـاً بعدم إفشاء هذه المعلومـات الصحية أو البيانات الثخصية الأخرى التي اطلع عليها بمقتضى الوسيلة التكنولوجية المستخدمة في العمل الطبي عن بعد. وحماية سرية البيانـات الثخصية للمريض هو التزام يقع على عاتق كل من يتعامل مع البيانات الثخصية للمريض أثناء القيام بالعمل الطبي عن بعد سواء أكـان الطبيب أو مساعدى الطبيب أو المختص في تكنولوجيا المعلومسات الذي يبرمج برامج العمل الطبي عن بعد، فدور المختص في تكنولوجيا المعلومات سيزيد في العمل الطبي عن بعد، مما يقتضي زيادة الالتزامات الملقاه على عاتقه في مواجهة المريض وأهمها

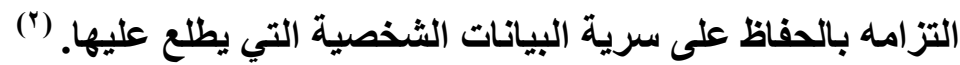
فالمادة (L. 1110-4) من قانون الصحة العامـة قد نصت على التزام كل من يتلخل في عملية علاج المريض بعدم إفشاء الأسرار التي يطلع عليها، وهذا ينطبق على المختص بتكنولوجيا المعلومات؛ لأنه يلعب دوراً رئيساً في العمل الطبي عن بعد،

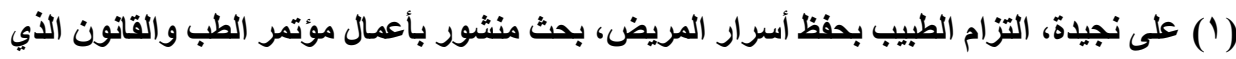

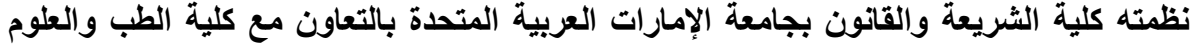

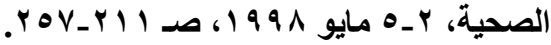

(2) Jean-Louis ARNÉ, Éthique: jurisprudence et télémédecine, Op.cit.

- Marcel POCHARD et Autres, Vade-mécum télémédecine, Op.cit, P 13. 
عدد خاص بالمؤتمر الدولى السنوى العشرون أ. د/ سامح عبد الواحد التهامى

فينطبق عليه نص المادة (L. 1110-4) من قانون الصحة العامـة، ويلتزم بعدم إفشاء أسرار المريض التي اطلع عليها بسبب أو بمناسبة قيامـه بدوره في العمل الطبي عن

بعد. (1)

ومن ناحية أخرى فقد نصت المـادة (R.6316-2-2) من قانون الصحة العامـة

على أن كل من يقوم بالعمـل الطبي عن بعد يحق لـه أن يستخدم وسيلة تكنولوجيـا

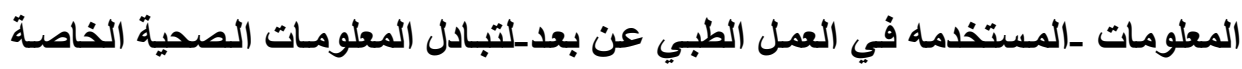
بالمريض في سبيل القيام بالعمل الطبي عن بعد، وذلك مالم يكن هنـاك اعتراض صريح من المريض على تبادل تلك البيانات بين القائمين بالعمل الطبي عن بعد.

فالأطباء الذين يتـداولون في حالـة المريض يحق لهم تبـادل بيانـات المـريض

الطبية باستخدام وسيلة تكنولوجيا المعلومات، وذلك في سبيل تبادل الخبرة الطبية أو تقديم المساعدة الطبية لمساعد الطبيب.

ومما لا شك فيه أن اعتراض المريض على تبادل بياناته الشخصية بين القائمين

بالعمل الطبي عن بعد، قد يؤدي إلى عدم قدرة الطبيب على القيام بالعمل الطبي عن بعد، وبالتالي يجب أن يخبر الطبيب المريض بعدم قدرته على القيام بالعدل الطبي عن بعد في هذه الحالة وأن يحاول القيام بالعمل الطبي في شكله التقليدي. (؟) ويترتب على نص المادة (R.6316-2-2) أن كل الأطباء الذين تداولوا في حالة المريض عن بعد عليهم التزام بالحفاظ على أسرار هذا المريض، فهذا الالتزام لا يقع

(1) Claire DEBOST, L'appréhension juridique de la relation de soin au prisme des nouvelles technologies, Op.cit.

(2) Droits des malades: La télémédecine, Fiche thématique du CISS, $n^{\circ} 46$, 2015. 
عدد خاص بالمؤتمر الدولى السنوى العشرون أ. د/ سامح عبد الواحد التهامى

على الطبيب المعالج للمريض فقط، ولكن يقع على أي طبيب آخر استشاره الطبيب المعالج في إطار تبادل الخبرة الطبية عن بعد.

\section{الإطلب الثالث}

\section{حماية رضاء المريض}

وفقاً للقواعد العامة فلا يحق للطبيب أن يباشر عملاً طبياً على جسم المريض إلا

بعـد الحصول علـى رضـاء هـذا المـريض، فيلزم لقيـام الطبيـب بـالعلاج أو العمليـات الجراحيـة الحصول على رضـاء المـريض بـلتك، وتزداد أهميـة الحصول على رضــاء المريض كلما كان العلاج ينطوي على كثير من المخاطر. (1)

ولا يمكن للمريض أن يختار بصورة سليمة إلا إذا أحيط علماً بالبدائل التي يختار

منها، فالعلم هو وسيلة الاختيار الواعي، ومن ثم يكون من الواجب على الطبيب أن الن الن لهن يفضي للمـريض بجميع المعلومـات اللازمـة لتــويره، على وجـه يمكن المـريض مـن التعبير عن إختيـاره عن وعي كامل بمـا يتم اقتراحه من عمل طبي، فالرضـا بالعمل

(الطبي يجب أن يكون مسبوقاً بالتبصير الكامل. (ن)

(1) محمد حسين منصور، المسؤولية الطبية، دار الجامعة الجديدة للنشر، الإسكندرية، 999 19 1، صـ (ץ) جابر محجوب على، دور الإرادة في العمل الطبي: دراسة مقارنة، مجلس النشر العلمي بجامعة

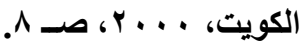


عدد خاص بالمؤتمر الدولى السنوى العشرون أ. د/ سامع عبد الواحد التهامى

فالالتزام بـالإعلام هو التزام يقع على عاتق الطبيب في جميع مراحل علاقته بالمريض، فهو يبدأ منذ مرحلة التشخيص، ويستمر في مرحلة العلاج، ويشمل أيضاً

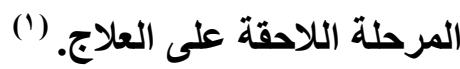

فيجب أن يـتم إعلام المـريض ببعض المعلومـات المتعلقة بالعمـل الطبي الذي سيخضع له قبل الحصول على رضـائه حتى يكون هذا الرضـاء رضـاءً مستتيراً، وهذا الأمر مطلوب في جميع الأعمـال الطبية، وبالتـالي مطلوب أيضاً في العمل الطبي عن بعد، إلا إن هناكك بعض المعلومات التي يجب إعلام المريض بها والتي تتعلق بطبيعة

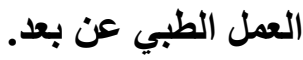

فوفقاً للمـادة (R-6316-2) من قـانون الصحة العامـة، فِإن أي عمل طبي يتم عن بعد يجب ألا يتم إجراؤه إلا بعد الحصول على رضاء حر وصريح من المريض مـع مراعاة المواد (L. 1111-2) و (L. 1111-4) من قانون الصحة العامة. وبالرجوع لنصوص المواد (L. 1111-2) و (L. 1111-4) من قانون الصحة العامـة، سـنجد أن هـذه المـواد تـنص على أن كل مـريض يجب أن يـتم إعلامـهـ بكل المعلومـات الخاصـة بحالتهـه الـصحية وبالعمـل الطبـي الــي يمكن القيـام بـه وبالآثـار المحتملة لهذا العمل، بحيث إن المريض يتخذ القرار في القيام بهذا العمل الطبي بنـاء على رضاء حر وصريح. وبالتالي، فإن من سيقوم بالعمل الطبي عن بعد يجب أن يخبر المريض بكل هذه المعلومات ويحصل على رضائه قبل القيام بذلك، ولكن ما يهمنا هنا هو أنها يجب إعلام

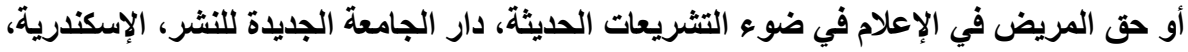


عدد خاص بالمؤتمر الدولى السنوى العشرون أ. د/ سامح عبد الواحد التهامى

المـريض بـأن هـا العمـل سـوف يـتم عن بعـد ومــاهي وسـيلة تكنولوجيـا المعلومـات المستخدمة، وأن بياناتـه الصحية سـوف يـتم تـداولها عبـر هذه الوسـيلة، وأن هنـاك أشخاصاً آخرين غير الكـادر الطبي يمكن أن يطلعوا على هذه المعلومـات أثناء القيـام بوظيفتهم وهم خبراء تكنولوجيا المعلومات المسؤلون عن تقنية العدل الطبي عن بعد

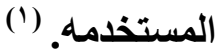

أي إن الطبيب الذي سـوف يقوم بالعمـل الطبي عن بعد عليـه إعلام المـريض بطبيعة العمل الطبي الذي سوف يقوم بـه وإعلامـه بالوسيلة التكنولوجية التي سوف يستخدمها للقيـام بهذا العمل الطبي، وبالتـالي فالطبيب عليسه الحصول على رضـاء المريض على القيام بالعمل الطبي وعلى استخدام الوسيلة التكنولوجية في القيام بهذا

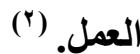

فضلا عن ذلتك فيجب أن يكون المـريض على علم بهويـة الطبيب الذي يقوم

بتقديم العمل الطبي للمريض عن بعد، وكذلك على علم بمؤهلات الطبيب، ومكان وجود الطبيب في لحظة تقديم العمل الطبي، ويرجع ذلك إلى أن المريض لايقابل الطبيب وجهاً لوجـه، ممـا يقتضي إخبـار المريض بهويـة الطبيب قبل موافقـة المريض على القيـام بالعمل الطبي عن بعد. (َ)

(1) Jean-Louis ARNÉ, Éthique: jurisprudence et télémédecine, Op.cit.

(2) Lina PELLITERRI, les aspects réglementaires de la télémédecine, Op.cit.

(3) Marcel POCHARD et Autres, Vade-mécum télémédecine, Op.cit, P 12. 
عدد خاص بالمؤتمر الدولى السنوى العشرون أ. د/ سامح عبد الواحد التهامى

فقد نصت المادة (R-6316-3) من قانون الصحة العامـة صراحة على أن أي عمل طبي يتم عن بعد يجب أن يكون فيه المريض على علم بهويـة الطبيب، وأن يكون

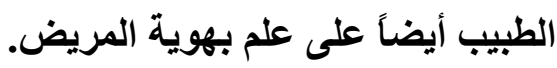

فالطبيـب قبـل أن يبــأ العمـل الطبـي، يجـب أن يخبـر المـريض بهويتـه، ففـي الاستشارة الطبية، يذكر الطبيب شخصيته للمريض، ويجب على الطبيب أن يطلع على هوية المريض، فمكن أن يطلع على ملفه الإكترونى أو يطلب منه إبراز بطاقة الهويـة

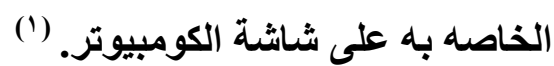
ووفقـاً للمـادة (L1111-7) مـن قـانون الـصحة العامـة، فـإن كـل مـريض مـن

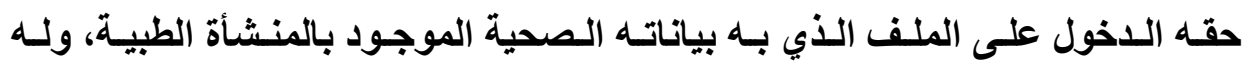
الحق في الاطلاع على كل مايحتويسه هذا الملف من بيانـات متداولـة بين الأطبـاء أو نتـائج الفحوصـات أو نتائج التحاليل والأثـعه والتقـارير الطبيـة وكل مـا يتعلق بحالته الصحية.

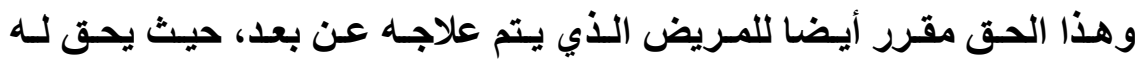
اللاخول للملف الإكترونـي الخـاص بحالته الـصحية والاطلاع على محتوياتـه، ولذلك نصت المادة (R 6316-4) من قانون الصحة العامة على أنه في العمل الطبي عن بعد يجب على الأطباء إنشاء ملف طبي إلكتروني للمريض يتضمن عدة ملفـات إلكترونية للأعمال الطبية التي تمت عن بعد بحيث يتضمن كل ملف على وجـه الدقة البيانـات

$$
\text { ا ـ العمل الطبي الأي تم عن بعد. }
$$

(1) Bernard LESPERANCE et Autres, Le médecin, la télémédecine et les technologies de l'information et de la communication, Op.cit, P 14. 
عدد خاص بالمؤتمر الدولى السنوى العشرون أ. د/ سامح عبد الواحد التهامى r ـ العلاج الذي تم تحديده والدواء الذي تم وصفه للمريض. بـ هوية كل شخص من أعضاء الفريق الطبي تدخل في هذا العمل الأي تم عن بعد. ـ ـ تاريخ ووقت العمل الطبي الأي تم عن بعد. هـ وجود أي مشكلة تقنية تكون قد واجهت الطبيب أثناء القيام بالعمل الطبي عن بعد. وهذا النص السابق المقصود منه تكوين ملف طبي الكتروني للمريض عن بعد، بحيث يستطيع الاخول عليه بسهوله والاطلاع على المعلومات الخاصة بحالته الصحيه، واسـتيفاء البيانـات التـي تطلبها النص السـابق تكـون سـهله عن طريـق البرمجيـات المستخدمة لاتمـام العمل الطبي عن بعد، اذ يستكمل الطبيب البيانـات بسهولة بحيث تدخل تلكك البيانات مباشرة إلى ملف المريض الإكترونى. ومن ناحية أخري فقى حالة تبادل الخبرة الطبية عن بعد، فبان الطبيب المعالج سيتبادل المعلومـات الصحية للمريض مـع طبيب آخر، فيجب على الطبيب المعالج أن يخبر المريض بهذا الأمر قبل القيام بذلك، ويجب على الطبيب المعالج أن يذكر للمريض هوية الطبيب الذي سيتبادل معه حالتة وأن يحصل على رضائه عن هذا العـل باعتباره صورة من صور العمل الطبي عن بعد. (1) وهذا مانصت عليه صراحة المادة (R.6316-2) من قانون الصحة العامـة بحق المريض في العلاج عن بعد في الاعتراض على تبادل بياناته الصحية عبر الوسـائل

(1) Nicolas SAMARCQ et Sébastien BRIOIS, Télémédecine : quel cadre juridique, Op.cit. 
عدد خاص بالمؤتمر الدولى السنوى العشرون أ. د/ سامح عبد الواحد التهامى

تكنولوجية وذلك بعد أن يتم إعلامه بأن بياناته يتم تبادلها بين الأطباء في إطار عملية تبادل الخبرة الطبية عن بعد.

ومن ناحية أخرى فقد نصت المادة (R316-10 6310) من قانون الصحة العامـة،

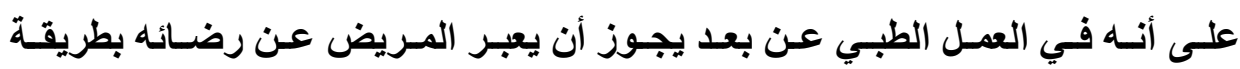
إلكترونية، أي يعبر عن رضائه عن بعد بذات وسيلة تكنولوجيا المعلومات التي يتواصل بها مع الطبيب لإجراء العمل الطبي، وهذا الحكم منطقى؛ لأن هذا المريض قد لا يقابل الطبيب إطلاقًا وجهاً لوجه، وقد لا يحضر للمنشأة الطبية بل يتلقى العلاج دون الانتقال من منزله.

ووفقاً للمادة (R.4127-36) من قانون الصحة العامـة فإنـه فى حالـة اعتر اض

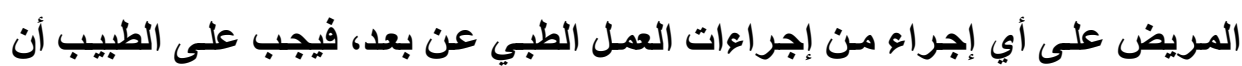
يحترم اعتراض المريض ويخبره بالآثار المترتبة على عدم القيام بهذا الإجراء من إجراعات العمل الطبي عن بعد، وأن يثبت ذلك في الملف الطبي للمريض، وأن يبذل كل الجهد للقيام بالعمل الطبي في صورته التقليديه إن أمكن ذلك. 
عدد خاص بالمؤتمر الدولى السنوى العشرون أ. د/ سامح عبد الواحد التهامى

\section{المبحث الثالث}

\section{كفاءة النظام المعلومهاتي}

يعتمد العمل الطبي عن بعد أساساً على نظام للاتصالات وتكنولوجيا المعلومـات، مما يؤدى إلى القول بأن المنشأة الطبية أو الطبيب في عيادته الخاصة عليه التزام بـأن يتيح نظاماً معلوماتياً ذو جودة مناسبة بحيث يسمح للمريض بتلقى العمل الطبي عن بعد في صورة جيذة، فلا يصيب هذا النظام العطل أثناء إجراء العمل الطبي ولا يكون نظام قديم يؤثر بشكل سلبي على جودة العمل الطبي ذاته.

فالعمل الطبي عن بعد يعتمد في بعض صوره على نقل الصوت والصورة من المريض للطبيب، والتفاعل المباشـر بينهم، أو التفاعل المباثـر بين الأطبـاء أو ببين الطبيب ومساعده، وهذا يتطلب نظام معلومـاتي كفؤ، بحيث يتم التفاعل بصورة جيدة وتنتقل البيانات الطبية بصورة صحيحة.

وهذا الأمر يلقى على عاتق المنشأة الطبية أو الطبيب في عيادته الخاصة التزام بتظوير النظام المعلوماتى للعمل الطبي عن بعد من آن إلى آخر، كلمـا ظهرت تحديثات للبرمجيات التي يتم إدارة النظام بها. كما يجب علي مقدم خدمـة العمل الطبي عن بعد أن يتعاقد مع فني تكنولوجيا المعلومات ليتولى صيانة هذا النظام وتحديثه ووضع البرمجيات التي تقوم بتأمينه حتى لا يكون عرضـة للاختراق أو التعطيل، خاصـة أنها يحتوى على بيانـات شخصية طبية للمرضى. 
عدد خاص بالمؤتمر الدولى السنوى العشرون أ. د/ سامع عبد الواحد التهامى

كما يتطلب العمل الطبي عن بعد أن تكون سرعة شبكة الإنترنت عالية، حتى يمكن نقل البيانات الطبية بسرعة كبيرة، وعدم انقطاع أو تأخر الاتصال أثناء إجراء

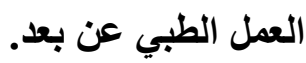

ولم يحدد القانون مستوى معين لكفاءة النظام المعلوماتي الأي يجب أن يلتزم به

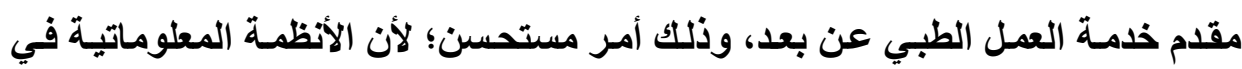
تطور مستمر، فما يتم النص عليه في القانون سيكون قديما بعد ذلك، ونرى أن الأمر يرجع إلى مدى حداثة البرمجيات الموجودة بالنسبة لأحدث إصدار للبرنـامج، فإذا كـان الفارق كبيراً، فيمكن القول بعدم كفاءة النظام المعلوماتي، أما إذا لم يكن الفـارق كبيراً، فيمكن القول أن النظام المعلوماتي ماز ال كفؤا.

كما أن الطبيب عليه التزام أن يتأكد من عدم وجود مشكلات تقنية في النظام

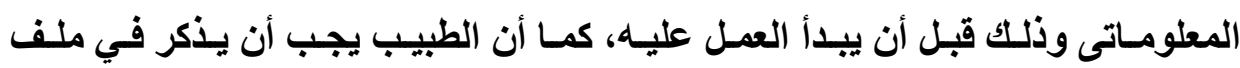
المريض وجود أيسة مشكلات تقتيه قابلته أثناء القيام بالعمل الطبي ولذلك فقد نصت

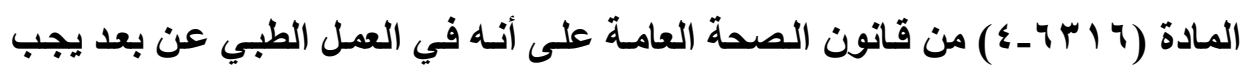
على الأطباء إنثاء ملف طبي للمريض يتضمن عدة بيانـات إحداها وجود أي مشكلة تقنية تكون قد واجهت الطبيب أثناء القيام بالعمل الطبي عن بعد.

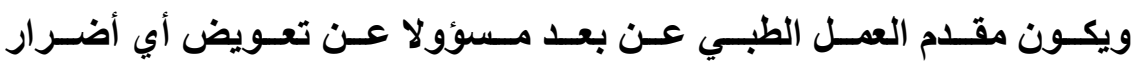
تــيب المـريض جـراء عـدم كفـاءة النظـام المعلومـاتى المسـتخدم فـي العــل الطبـي عن بعد. ولكن تظل هنـاك مشكلة الخوف من اختراق النظـام المعلومـاتي المستخدم في العمل الطبي عن بعد وسرقة بيانات المرضي أو الاطلاع على العمل الطبي وهو يتم عن 
عدد خاص بالمؤتمر الدولى السنوى العشرون أ. د/ سامح عبد الواحد التهامى

بعد، ومما لا شك فيه أن ذلك انتهاك خطير لخصوصية هذا المريض الذي يتم علاجه عن بعض، أو يتم تداول بياناته الصحية بين الأطباء عن بعد. (') فـالخطر الذي يمثلـه اختراق هذه الأجهزة يفـوق التخـوف مـن إفشاء بياتـات المريض من قبل العاملين في منظومـة العمل الطبي عن بعد؛ لأن هؤلاء العاملين من أطباء عليهم التزام قـانونى كمـا ذكرنـا سـالفاً بالحفـاظ على خصوصية المـريض بعدم إفشـاء أسراره ومراعاة قواعد حماية البيانات الشخصية الواردة في قانون المعلوماتية وحماية البيانات والحريات.

فمشكلة العمل الطبي عن بعد أن وسائل تقنية المعلومات المستخدمة للقيسام بهذا العمل الطبي تكون مربوطة بشبكة الإنترنت حتى يمكن القيام بتبادل المعلومـات بين الطبيب والمريض أو بين الأطباء بعضهم البعض عن بعد، مما يؤدي إلى إمكانيـة دخول طرف ثالث واختراق هذا الاتصال عن بعد، كما يحدث في اختراق الأنظمـة المعلوماتيـة إنـ المتصلة بشبكة الإنترنت.

ولـلك فقد نـصت المسادة (R-10-6316) مسن قـانون الصحة العامسة على أن

المنشآت الصحية والأفر اد التي تقوم بالعمـل الطبي عن بعد يجب أن تتأكد مـن أن البرمجيـات التـي تستخدمها في تقديم العـل الطبـي عن بعد تحترم القواعد الخاصـة بحمايـة البيانـات الثخصية للمريض، فهذه المـادة قد ألقت بـالتزام على عـاتق هذه المنشآت بـأن تقوم بالتأمين التقـي للوسـائل المستخدمة في العمل الطبي عن بعض، وهذا يقتضي استخدام أحدث وسائل تأمين الأنظمة المعلوماتية من جانبها. (†)

(1) Jean HERVEG, Confidentialité et sécurité pour les applications de télémédecine en droit européen, Op.cit.

(2) Marcel POCHARD et Autres, Vade-mécum télémédecine, Op.cit, P 13. 
عدد خاص بالمؤتمر الدولى السنوى العشرون أ. د/ سامح عبد الواحد التهامى

فالمنششأة الطبيـة التـي تقـدم خدمـة العمـل الطبـي عـن بعـد ملتزمسة بـأن تقوم

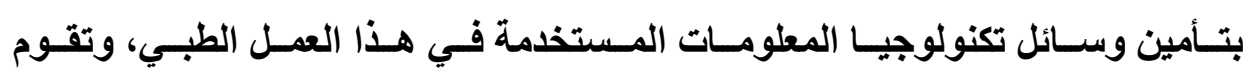
بتثفير البيانـات الثخصية للمرضسي أثناء تبادلها عبر وسـائل تكنولوجيا المعلومـات،

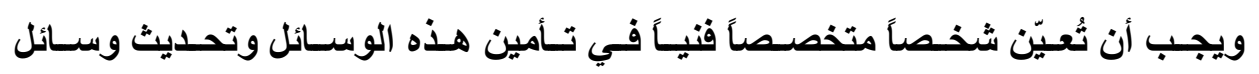

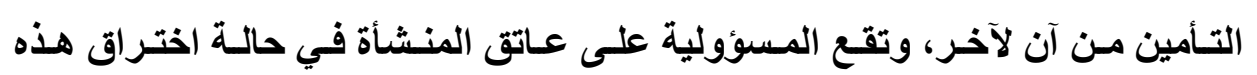
الوسائل. (')

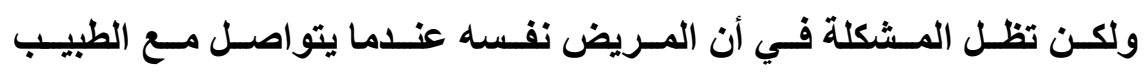
عن بعد، فقد لا يستخدم برمجيات لتأمين الكومبيوتز أو الهاتف الذكي الخـاص بـه ممـا

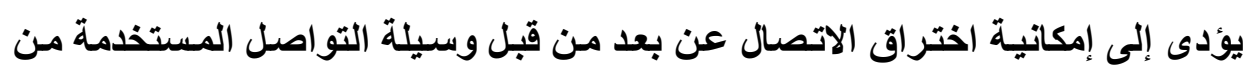
المريض.

وأعتقد أن حل هذه الإشكالية يكون بـالرجوع إلى المـادة (R-316-3 6316) من قانون الصحة العامة التي نصت على أنسه في العمل الطبي عن بعد، إذا تطلب الأمر، فيجب أن يتم تدريب المريض على استخدام وسيلة العمل الطبي عن بعد قبل البدء في هذا العمل الطبي.

وبالتالي فإنه يمكن القول إن المنشأة الطبية التي تقلم العلاج عن بعد أو الطبيب

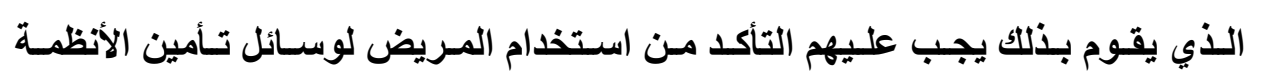
المعلوماتية كبرنامج مكافحة الفيروسات وبرنامج منع الاختراق.

(1) Jean-Louis ARNÉ, Éthique: jurisprudence et télémédecine, Op.cit.

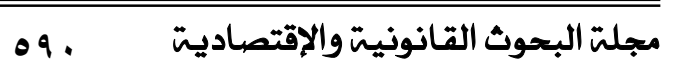


عدد خاص بالمؤتمر الدولى السنوى العشرون أ. د/ سامح عبد الواحد التهامى

\section{الخاتمة}

تناولت الدراسة التي بين دفتي البحث موضوع (التنظيم القانوني للعدل الطبي عن بعد: دراسة في القانون الفرنسي)، وسوف نستعرض ما توصلت إليه هذه الدراسـة من نتائج وتوصيات.

\section{أولاًا-النتائج:}

1 - وضع المشرع الفرنسي في قانون الصحة العامة تنظيماً قانونياً متكاملاً للعمل الطبي عن بعد، حيث قام المشرع الفرنسي بإضـافة هذا التظظيم لقانون الصحة العامـة

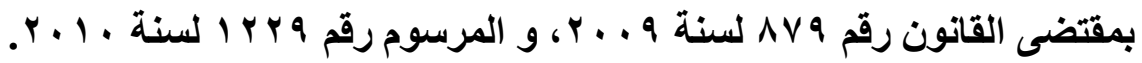
ץ - صور العمل الطبي عن بعد تتمثل في الاستثارة الطبية عن بعد، تبادل الخبرة الطبية

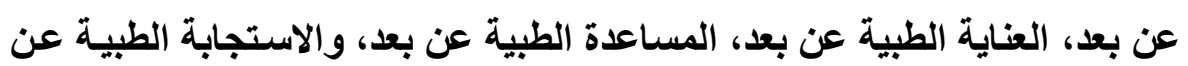
بعد، وكل صورة من هذه الصور من الممكن أن تحقق هدفاً أو أكثر من أهداف

$$
\text { العمل الطبي والمتمثلة في التشخيص والوقاية والعلاج. }
$$

rـ نص قانون الصحة العامة الفرنسي على وجوب تمتع الأطباء أو المعالجين النفيين أو طبيب الأسـنان أو مساعديهم الذين يمارسـون العمل الطبي عن بعد بالمعرفـة والمهارات التقنية التي تسمح لهم باستخدام البرمجيات الخاصة بالعمل الطبي عن بعد. ع ـ نص قـانون الصحة العامـة الفرنسي على أنه في العمل الطبي عن بعد-إذا تطلب الأمر-فيجب أن يتم تدريب المريض على استخدام وسيلة العمل الطبي عن بعد قبل البدء في هذا العمل الطبي. 
عدد خاص بالمؤتمر الدولى السنوى العشرون أ. د/ سامع عبد الواحد التهامى

هـ نص قانون الصحة العامة الفرنسي على أن أي منشأة أو طبيب يقوم بالعمل الطبي عن بعد يجب أن يتأكد من أن البرمجيات المستخدمة في تقديم العمل الطبي عن بعد تحترم قواعد حماية البيانـات الثخصية المنصوص عليها في قانون المعلوماتية وحماية البيانات والحريات.

צـ نص قانون الصحة العامة الفرنسي على أن أي عمل طبي يتم عن بعد يجب ألا يتم إجـراؤه إلا بعـد الحصول على رضساء حـر وصـريح مـن المـريض، بعــ إعلامـهـ بخصوصية العمل الطبي عن بعد، ويجوز الحصول على رضاء المريض إلكترونياً. Vـ تلتزم المنشأة الطبية أو الطبيب في عيادته الخاصة بتوفير نظام معلوماتى ذي جودة عالية للعمل الطبي عن بعد، كما تلتزم بتطوير النظام المعلومـاتى للعمل الطبي عن بعد من آن إلى آخر، كلمـاظهرت تحديثات للبرمجيات التي يتم إدارة النظام بها، ويلتزم بتأمين هذا النظام لمنع اختر (قه.

ثانيًا-التوصيات: بعد أن انتهينا من هذه الدراسة، فإننا نوصي بالآتي: ا -أن يهتم المشرع في الدول العربية بوضع القواعد التشريعية التي تحكم الممارسـات الطبية الحديثة، وخاصة العمل الطبي عن بعد باعتبـاره صورة حديثة وهامسة من صور العمل الطبي ويمكن أن تؤدى لحدوث طقرة في تقديم العمل الطبي في هذه الدول.

r -أن تقوم كليات الطب في الجامعات العربية بتدريس مقرر للعمل الطبي عن بعد ضمن برنـامج الكليـة، بحيث يتضمن الجوانب التقنيـة للعمل الطبي عن بعد وتـريب الطلاب عليها فضلاً عن تتاول الجوانب القانونية لهذا العمل. 
عدد خاص بالمؤتمر الدولى السنوى العشرون أ. د/ سامح عبد الواحد التهامى

\section{قائمة المراجع}

$$
\text { أولا-مراجع باللغة العربية: }
$$

- جـابر محجـوب على، دور الإرادة في العمل الطبي: دراسـة مقارنـة، مجلس النشر

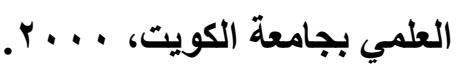

ـ سامح عبد الواحد التهامي، الحماية القانونية للبيانات الثخصية: دراسة في القانون

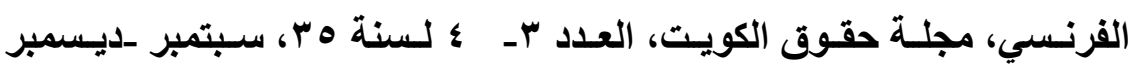

$$
.11
$$

ـ على نجيذة، التزام الطبيب بحفظ أسرار المريض، بحث منشور بأعمال مؤتمر الطب والقانون الذي نظمته كلية الثريعة والقانون بجامعة الإمـارات العربية المتحدة

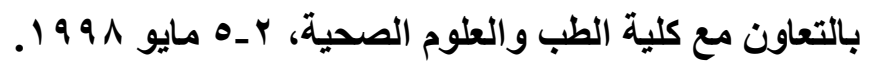

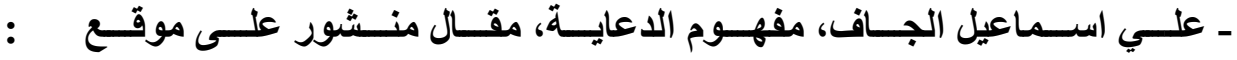
Www.tellskuf.com

ـ محسن عبد الحميد البيه، التزامسات الأطباء المتصلة بواجباتهم الإنسانية والأخلاقية والأعمال الفنية، بحث منشور بأعمال مؤتمر الطب والقانون الذي نظمته كلية الشريعة والقانون بجامعة الإمـارات العربية المتحدة بالتعاون مـع كلية الطب

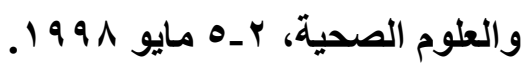

ـ محمد حسن قاسم، الطب بين الممارسـة وحقوق الإنسان: دراسـة في التزام الطبيب بإعلام المريض أو حق المريض في الإعلام في ضوء التشريعات الحديثة، دار

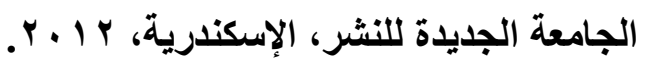


عدد خاص بالمؤتمر الدولى السنوى العشرون ا.. د/ سامع عبد الواحد التهامى

ـ محمد حسين منصور، المسؤولية الطبية، دار الجامعة الجديدة للنشر، الإسكندرية، .1999

ثانيا-مراجع باللغة الإنجليزية:

-Bill MARINO \& others, A Case for Federal Regulation of Telemedicine in the Wake of the Affordable Care Act, Colum. Sci. \& Tech. L. Rev, VOL. XVI, spring 2015, pp 274-357.

-Caroline WHITBECK, What is diagnosis? Some critical reflections, Metamedicine, October 1981, Volume 2, Issue 3, pp 319-329.

-Francis SERBAROLI, Telemedicine: Legal and Practical Considerations, NYLJ, V. 251, N 100, 27 MAY 2014.

-Katherine Kuchenbecker, The technology of touch, Talk Video,

https://www.ted.com/talks/katherine_kuchenbecker_the_te chnology_of_touch, the date of acces is: 18 November 2016.

- Mark KADZYELSKI \& Jee KIM, Telemedicine: Many Opportunities, Many Legal Issues, Many Risks, AHLA Connections Journal (July 2014). 
عدد خاص بالمؤتمر الدولى السنوى العشرون أ. د/ ساميح عبد الواحد التهامى

- Michael COHEN, Telemedicine: The Future of Health Care, Art on the internet at: www.legalzoom.com, the date of publishing is: February 2014.

- Sajeesh KUMAR and others, Tele-ICU: Efficacy and CostEffectiveness Approach of Remotely Managing the Critical Care, Open Med Inform J. 2013; 7: 24-29.

$$
\text { ثالثا_مر اجع باللغة الفرنسية: }
$$

- Anaïs RICHARDIN, Face à la rigidité réglementaire française: la télémédecine peut-elle révolutionner la santé?, Art disponible sur: https://www.maddyness.com/author/anais-richardin/, La date de mise en ligne est: 21 mars 2016.

- Anastasie KERLUEN, La télémédecine en question: quand la médecine utilise les nouvelles technologies de l'information, Art disponible sur: www.blog-dmi.com, la date de mise en ligne est: 29 janvier 2011.

- Anne BEAUFORT et Alice PHILIPPOT, Innovation médicale: le corps ou l'objet?, Art disponible sur: www.tendancedroit.fr/lin novation-dans-le-domaine-delasante, la date de lire: 11 décembre 2016. 
عدد خاص بالمؤتمر الدولى السنوى العشرون أ. د/ ساميح عبد الواحد التهامى

-Anne-Sophie MAZEIRAT, La télémédecine: nouvelle pratique médicale, Art disponible sur: www.prevention.sham.fr, La date de mise en ligne est: 7/04/2011.

- Bernard HCERNI, Appels téléphoniques des patients et déontologie médicale, Rapport adopté lors de la session du Conseil national de l'Ordre des médecins, juillet 1998.

- Bernard LESPERANCE et Autres, Le médecin: la télémédecine et les technologies de l'information et de la communication, guide d'exercice, Collège des médecins du Québec, 2015.

- Camille BOURDAIRE-MIGNOT, « Téléconsultation : quelles exigences ? Quelles pratiques ? », RDSS, Nov. déc. 2011, $n^{\circ}$ 6, p. 1003.

- Cécile FRATELLINI, Télémédecine: se soigner à distance, Art disponible sur: http://www.essentiel-santemagazine.fr/sante/acces-aux-soins/telemedecine-soindistance, la date de mise en ligne est: 24/09/2013.

- Cécile MONTEIL, Télémédecine: quand l'Ordre des Médecins se met en colère, Art disponible sur: http:www.lequotidiendumedecin.fr, la date de mise en ligne est: 24 février 2016. 
عدد خاص بالمؤتمر الدولى السنوى العشرون أ. د/ ساميح عبد الواحد التهامى

- Christophe COURAGE, Prescriptions médicales européennes: un coup de pouce pour la télémédecine, Art disponible sur: www.juritravail.com, La date de mise en ligne est: 21-012014.

- Claire DEBOST, L'appréhension juridique de la relation de soin au prisme des nouvelles technologies, Jurisdoctoria, $n^{\circ} 8,2012$, P 103-129.

- David GRANEL, E-santé, la téléconsultation peine à se développer en France, Art disponible sur: www.jurilexblog.com, la date de mise en ligne est: 25 avril 2016.

- David GRUSON, IL faut déverrouiller le modèle économique de la télémédecine, Art disponible sur: www.editionslegislatives.fr, La date de mise en ligne est: 22/07/2016.

- Denis PIVETEAU, La recherche d'un nouveau modèle économique, en dossier: Quelle santé à domicile pour demain?: Enjeux et perspectives, Fédération des prestataires de santé à domicile, France, Janvier 2015.

- François BOURDILLON, Agences regionales de santé: promotion, prévention et programmes de santé, Ed INPES, Santé Denis, France, 2009. 
عدد خاص بالمؤتمر الدولى السنوى العشرون أ. د/ ساميح عبد الواحد التهامى

- Jean HERVEG, Confidentialité et sécurité pour les applications de télémédecine en droit européen, revue hospitalière de France, vol. 12, $\mathrm{n}^{\circ} 1$ (Printemps / Spring 2007).

- Jean-Louis ARNÉ, Éthique: jurisprudence et télémédecine, Bull. Acad. Natle Méd, 2014, 198, n 1, P 119-130.

- Jessica Nadeau, La psychothérapie à distance pour traiter l'anxiété généralisée, Art disponible sur: http:www.ledevoir.com, La date de mise en ligne est: 8 juillet 2015.

- Jesus CARDENAS, Des avancées dans la pratique de la médecine à distance, Art disponible sur: www.doctissimo.fr, La date de mise en ligne est: 26 mai 2016.

- Lina PELLITERRI, les aspects réglementaires de la télémédecine, en (Télémédecine: état des lieux, perspectives et opportunités), Compte-rendu de conférence, Eurasanté, Jeudi 09 février 2012.

- Marcel POCHARD et Autres, Vade-mécum télémédecine, conseil national de l'Ordre des médecins, France, SEPT 2014. 
عدد خاص بالمؤتمر الدولى السنوى العشرون أ. د/ ساميح عبد الواحد التهامى

- Michaël Balavoine, télémédecine: L'exemple valaisan, Art disponible sur: https://www.planetesante.ch, La date de mise en ligne est: 14/03/2011.

- Nathalie BESLAY, La conduite juridique d'un projet de télémédecine, Art disponible sur: http://www.magazinedecideurs.com/news/la-conduite-juridique-d-un-projet-detelemedecine, La date de mise en ligne est: 18-11-2014.

- Nathalie DEVILLIER, La télémédecine: une innovation de rupture, Art disponible sur: www.lesechos.fr, la date de mise en ligne est: 02/06/2015.

- Nicolas GIRAUDEAU, L'acte médical à l'épreuve de la télémédecine bucco-dentaire, thèse pour obtenir le grade de docteur, l'école doctorale Droit et Science politique Et de l'unité de recherche, Université Montpellier 1, 2014.

- Nicolas SAMARCQ et Sébastien BRIOIS, Télémédecine: quel cadre juridique, Art disponible sur: http://www.echosjudiciaires.com/category/culture/gironde-actualites, La date de mise en ligne est: 28 décembre 2012.

- Olivier MONNIER, La télémédecine: une chance pour l'Afrique, Art disponible sur: www.la-croix.com, La date de mise en ligne est: 10 June 2013. 
عدد خاص بالمؤتمر الدولى السنوى العشرون أ. د/ ساميح عبد الواحد التهامى

- Patricio Costa LOUREIRO, Télésanté: télémédecine en pharmacie et télépharmacie : les nouvelles technologies de l'information et de la communication au service de la santé, Thèse pour l'obtention du Diplôme d'Etat de docteur en pharmacie, Univ de Bordeaux, 2016.

- Philippe BURNEL, la télésanté, en dossier: Quelle santé à domicile pour demain?: Enjeux et perspectives, Fédération des prestataires de santé à domicile, France, Janvier 2015.

- Pierre SIMON et Dominique ACKER, La place de la télémédecine dans l'organisation des soins, Rapport de direction de l'hospitalisation et de l'organisation des ssoins, Ministère de la Santé et des soins, France, 2008.

- Pierre SIMON et Jacques LUCAS, La télémédecine: ce n'est pas du e-commerce, Rev de la Recherche Européenne en Télémédecine, V.3, Issue 1, March 2014, PP 27-34.

- Pierre SIMON, la télémédecine clinique: un modèle français, Lex Electronica, $n^{\circ}$ 560, septembre - octobre 2014, $P$ 42-45.

- S. Halimi, « Télémédecine oui mais sans délaisser la relation directe avec les patients ", Médecine des maladies métaboliques, vol. 4, $\mathrm{N}^{0}$ 3, mai 2010. 
عدد خاص بالمؤتمر الدولى السنوى العشرون أ. د/ ساميح عبد الواحد التهامى

- Stéphane ASTIER, Télémédecine et Télésurveillance médicale: quelles contraintes juridiques?, Art disponible sur: www.haas-avocats.com, La date de mise en ligne est: 22 Janvier 2014.

- Thierry SIRDEY, Prudence avec les applications mobiles et les logiciels de santé, Art disponible sur: www.larecherche.fr/parution/mensuel-510, la date de mise en ligne est: avril 2016.

- Thomas SYBURRA et Michele GENONI, Applications de la télémédecine en Suisse, Rev Med Suisse, 2008, 4, P 26522656.

- Vincent RICOULEAU, Les enjeux juridiques de la télémédecine, Art disponible sur: www.Village-justice.com, la date de mise en ligne est: 21 octobre 2014.

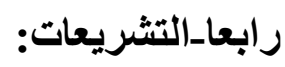

- Code de la santé publique, Version consolidée au 15 février 2017, disponible sur: www.legifrance.gouv.fr.

- Loi n $^{\circ}$ 2009-879 du 21 juillet 2009 portant réforme de l'hôpital et relative aux patients, à la santé et aux territoires, JORF, $n^{\circ} 0167$ du 22 juillet 2009, p 12184, texte $n^{\circ} 1$. 
عدد خاص بالمؤتمر الدولى السنوى العشرون أ. د/ ساميح عبد الواحد التهامى

- Loi n 2004-810 du 13 août 2004 relative à l'assurance maladie, JORF, $n^{\circ} 0190$ du 17 août 2004, p 14598, texte $n^{\circ} 2$.

- Loi $n^{\circ}$ 78-17 du 6 janvier 1978 relative à l'informatique, aux fichiers et aux libertés, modifeé par loi $n^{\circ}$ 2016-1321 du 7 octobre 2016 pour une République numérique, JORF, $n^{\circ} 0235$ du 8 octobre 2016, texte $n^{\circ} 1$.

- Décret $n^{\circ}$ 2013-1216 du 23 décembre 2013 relatif à la reconnaissance des prescriptions médicales établies dans un autre Etat membre de l'Union européenne, JORF, n0300 du 27 décembre 2013, P 21474, texte n 21.

- Décret $\mathrm{n}^{\circ}$ 2010-1229 du 19 octobre 2010 relatif à la télémédecine, JORF, n0245 du 21 octobre 2010, texte n $^{\circ}$ 13.

- Ordonnance $n^{\circ} 2017-48$ du 19 janvier 2017 relative à la profession de physicien médical, JORF, $\mathbf{n}^{\circ} 17,20$ janvier 2017, texte $n^{\circ} 23$.

$$
\text { ج-تشريعات أوربية: }
$$

- Directive d'exécution 2012/52/UE de la Commission du 20 décembre 2012, établissant des mesures visant à faciliter la reconnaissance des prescriptions médicales établies dans 
عدد خاص بالمؤتمر الدولى السنوى العشرون أ. د/ ساميح عبد الواحد التهامى

un autre État membre, JOUE, L 356, 55 e année, 22 décembre 2012, p 68.

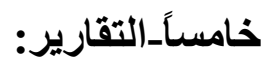

- Education thérapeutique du Patient: Programmes de formation Continue pour professionnels de soins dans le domaine de la prevention des maladies chroniques», Organisation Mondiale de la Santé, 1998, p. 10, disponible sur:

http://www.euro.who.int/ data/assets/pdf file/0009/14529 6/E93849.pdf.

- Education thérapeutqiue du patient: Définition, finalités et organisation, Haute Autorité de Santé, 2007, p. 8, disponible sur: $\quad$ http://www.hassante.fr/portail/upload/docs/application/pdf/etp definition finalites - recommandations juin 2007.pdf

- Droits des malades: La télémédecine, Fiche thématique du CISS, $n^{\circ} 46,2015$.

$$
\text { سادسا_الميثاق العالمي لآداب مهنة الطب: }
$$

- International Code of Medical Ethics, Adopted by the 3rd General Assembly of the World Medical Association, London, England, October 1949, and amended by the 57 
عدد خاص بالمؤتمر الدولى السنوى العشرون ا. د د ساميح عبد الواحد التهامى th WMA General Assembly, Pilanesberg, South Africa, October 2006, available at:

http://www.wma.net/en/30publications/10policies/c8/index. html. 